\title{
Treatment of high-burden hepatocellular carcinoma: an oncologist perspective
}

\author{
Landon L. Chan ${ }^{1}$, Stephen L. Chan ${ }^{1,2,3,4}$ \\ 'Faculty of Medicine, The Chinese University of Hong Kong, Hong Kong, China. \\ ${ }^{2}$ State Key Laboratory of Oncology in South China, Hong Kong, China. \\ ${ }^{3}$ Sir YK Pao Center for Cancer, Department of Clinical Oncology, Hong Kong Cancer Institute, Prince of Wales Hospital, The Chinese \\ University of Hong Kong, Hong Kong, China. \\ ${ }^{4}$ Institute of Digestive Disease, The Chinese University of Hong Kong, Hong Kong, China.
}

Correspondence to: Dr. Stephen L. Chan, Department of Clinical Oncology, Prince of Wales Hospital, Shatin, New Territories, Hong Kong, China. E-mail: chanlam_stephen@cuhk.edu.hk

How to cite this article: Chan LL, Chan SL. Treatment of high-burden hepatocellular carcinoma: an oncologist perspective. Hepatoma Res 2018;4:5. http://dx.doi.org/10.20517/2394-5079.2017.49

Received: 29 Nov 2017 First Decision: 17 Jan 2018 Revised: 22 Jan 2018 Accepted: 22 Jan 2018 Published: 7 Feb 2018

Science Editor: Guang-Wen Cao Copy Editor: Jun-Yao Li Production Editor: Huan-Liang Wu

\begin{abstract}
Hepatocellular carcinoma (HCC) is recognized as a major global healthcare burden. Although there have been tremendous improvements in cancer screening and treatment, HCC mortality rate remains high. Many patients with HCC present late to medical attention and thus are not candidates for curative treatment. They typically have high tumor burden at presentation showing heterogeneity in anatomical factors and biochemical profile. Despite the relatively poor prognosis for these patients, significant improvements can still be made in survival if the optimal treatment modality is chosen. Currently, there is no international consensus on how to manage this group of heterogeneous, high-burden HCC. In this article, we will address this question by reviewing the latest available evidences. Our definition of "high-burden HCC" will be based on three factors: size, number of tumors and the presence of macrovascular invasion. The different treatment modalities, namely surgery, intra-arterial therapy, radiotherapy and systemic therapy, and their respective supportive evidences, will be discussed. In the end, we will summarize with our views on the future direction of research priorities for the management of high-burden HCC.
\end{abstract}

Keywords: Cancer, hepatocellular carcinoma, liver

\section{INTRODUCTION}

Hepatocellular carcinoma (HCC) is a major healthcare burden in the world. It represents $6 \%$ and $9 \%$ of the global cancer incidence and mortality respectively ${ }^{[1]}$. It is the second most common cause of cancerrelated death worldwide ${ }^{[1]}$. Although major advancements have been made in cancer screening, diagnosis

\footnotetext{
(@) (-)

(C) The Author(s) 2018. Open Access This article is licensed under a Creative Commons Attribution 4.0 International License (https://creativecommons.org/licenses/by/4.0/), which permits unrestricted use, sharing, adaptation, distribution and reproduction in any medium or format, for any purpose, even commercially, as long as you give appropriate credit to the original author(s) and the source, provide a link to the Creative Commons license, and indicate if changes were made.
}

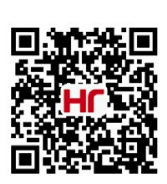


and treatment, prognosis of liver cancer remains poor. In 2012, World Health Organization estimated the incidence-to-mortality ratio of liver cancer to be as high as $95 \%{ }^{[1]}$.

One of the major challenges in treating HCC is its heterogeneity and complexity. In contrast to other cancers, the prognosis of HCC not only depends on the tumor load, but also on the underlying etiology as well as the remaining liver reserve. Multiple staging systems have been proposed in the management of HCC. Many of them classify the patients into three groups. The first group of patients are those with the best prognosis, with little tumor burden and good liver reserve. They are often offered treatment with curative intent. The second group represents those patients with advanced disease of which tumor load is high and liver reserve is poor. These patients have very few treatment options and are offered systemic therapy, enrollment into clinical trials or supportive treatment.

The third group is the intermediate group which includes patients who do not fulfill the criteria of the first and second group. They have high tumor burden yet with relatively good liver reserve, and are potential candidates for multiple or combination of therapies, some of which can be with curative intent. This is the group which is made up of the most heterogeneous patient population, and hence it remains a challenge to devise the best therapeutic strategy for them.

In this review, the latest therapeutic options for this heterogeneous, high-tumor burden group of HCC patients will be discussed. Firstly, we will define our target population of high-burden HCC based on the size, the number of tumors, and the presence of portal vein invasion. Secondly, we will outline the various therapeutic options available and evaluate their impact on survival. Thirdly, we will briefly discuss the etiological adjunctive treatment for high-burden HCC. Finally, we will summarize the future directions in the management of high-burden HCC.

\section{DEFINITION}

Multiple factors have been identified to affect the survival rates of patients with HCC. While many of them are surrogate markers of liver reserve, a few anatomical factors have also been found to persistently affect prognosis ${ }^{[2-4]}$, including the size, the number of tumors and the presence of portal vein invasion. The application of these anatomical factors is important because it affects the choice of optimal treatment modalities.

Historically, large HCC is defined as tumors of size $\geq 5 \mathrm{~cm}$, owing to the poor efficacy of radiofrequency ablation in managing HCC beyond that size. This is also the cutoff used in the Barcelona Clinic Liver Cancer (BCLC) staging system to classify tumors which are not amenable to curative treatment. Multiplicity of tumor is usually defined as number of tumors $\geq 3$, and the higher number of tumors means curative treatment would unlikely be successful. Portal vein invasion is another important poor prognostic indicator, not only because it indicates an advanced disease, it would also limit the number of feasible treatment options. According to BCLC, portal vein invasion is a contraindication for transarterial chemoembolization (TACE). As a result, only systemic therapy and best supportive care are feasible options for this group of patients.

The focus of our discussion will be on treatment options available to high-burden HCC, which we define as HCC satisfying the following criteria: (1) presence of any tumor of size $\geq 5 \mathrm{~cm}$; (2) number of tumors $\geq 3$; (3) presence of portal vein invasion; and (4) without extrahepatic metastasis. This group of patients were traditionally considered to carry a grim outlook but recent treatment advancements have improved their prognosis.

\section{TREATMENT OPTIONS FOR HIGH-BURDEN HCC}

In the literature, a plethora of therapeutic options are available for high-burden HCC. These include surgery, TACE, transarterial radioembolization (TARE), radiotherapy (RT) and systemic therapy. The choice of 
therapy depends on the extent of the disease, the liver function and the patient's performance status. Each treatment option will be discussed individually here.

\section{Surgery}

Previously thought only to have a role in early HCC, advancement in surgical techniques have enabled hepatic resection to become a therapeutic option for high-burden HCC. Although high quality evidence is still lacking, many retrospective studies have provided support for hepatic resection to be a safe and effective method in managing high-burden HCC. In fact, many Asian liver centers prefer hepatic resection, as long as it is feasible, to other local treatment options. We will now review the recent studies published between 2007 and 2017 to give the most updated picture of the efficacy of hepatic resection in the management of high-burden HCC $^{[5-39]}$ [Table 1]. Of note, few studies have examined the effect of tumor size and number of tumors independently on survival, so we would group them together in the following discussion, with large ( $\geq$ $5 \mathrm{~cm}$ ) and multifocal tumor as one single population (large/multifocal HCC).

For patients with large/multifocal high-burden HCC treated with surgery, the median survival rate was 27.6 months, and the median 1-, 3-, and 5-year overall survival rates were $74.3 \%, 51.2 \%$, and 39.2\% respectively. Among patients treated with surgery, survival was particularly favorable among those with solitary large tumor $(\geq 5 \mathrm{~cm}$ ), with median 1-, 3-, and 5-year survival rates of $87.2 \%, 63.2 \%$, and $56.1 \%$ respectively. Large tumor size has been repeatedly reported as a poor prognostic factor for HCC. This is consistent with the results we found in high-burden HCC treated with surgery [Table 2]: the median 1-, 3-, and 5-year overall survival rates for huge/multifocal tumor $(\geq 10 \mathrm{~cm})$ were $70.0 \%, 45.0 \%$, and $36.0 \%$, whereas those for moderately-large/multifocal tumors $(\geq 5$ and $<10 \mathrm{~cm}$ ) were $73.0 \%, 55.1 \%$, and $50.8 \%$ respectively. However, it is worth noting that larger tumors do not appear to be associated with higher post-operative mortality. The median postoperative mortality for huge/multifocal $(\geq 10 \mathrm{~cm})$ tumors was $2.6 \%$, compared with $4.3 \%$ for large/multifocal tumors.

Portal vein invasion remains to be another poor prognostic factor for HCC patients despite advancements in treatment modalities, especially for tumors invading into the main or contralateral portal vein ${ }^{[40]}$. Surgery has been considered contraindicated by many institutions, including the BCLC system ${ }^{[41]}$. However, many studies, particularly those from the Asian centers, have reported hepatic resection to be safe and effective for patients with portal vein invasion ${ }^{[28,42-58]}$ [Table 3]. The median 1-, 3- and 5-year overall survival rates for patients with all forms of portal vein invasion treated with surgery were $61.0 \%, 32.9 \%$ and $27.0 \%$ respectively. The prognosis worsens with the degree of portal vein involvement [Table 4]. For Vp1 and Vp2 involvement, the median 1-, 3- and 5-year overall survival rates after surgery were $69.1 \%, 42.2 \%$ and $38.7 \%$, whereas for those with main portals or the 1st branch involvement (Vp3 and $\mathrm{Vp} 4$ ), the median 1-, 3- and 5-year overall survival rates after surgery were $52.8 \%, 23.4 \%$ and $14.6 \%$ respectively [Table 5].

\section{Transarterial chemoembolization}

Before the advent of intra-arterial therapy, surgery has been the mainstay of treatment for HCC. However, less than $30 \%$ of patients were eligible for liver resection due to advanced staging of the disease ${ }^{[5,60]}$. TACE revolutionized the treatment for high-burden HCC when it was first introduced in the early 90's ${ }^{[61-65]}$. It takes advantage of the differential portal and arterial contributions to the blood supply of the tumor and the normal liver parenchyma. Normal liver parenchyma receives majority of the blood supply from the portal vein while the tumor feeds itself mainly from the hepatic arteries. The effects of TACE are two-fold. First, it delivers cytotoxic drugs to kill tumor cells. At the same time, by embolization of the arterial supply to the tumor, it creates an ischemic environment while keeping the cytotoxic agents within the tumor. The overall effect is to induce tumor necrosis via both direct poisoning and starvation.

Nowadays, TACE is the treatment of choice for unresectable high-burden HCC. The positive efficacy of TACE has been reported in numerous case reports and retrospective studies since its introduction in 
Table 1. Recent studies on the efficacy of surgical resection in the management of large/multifocal high-burden hepatocellular carcinoma

\begin{tabular}{|c|c|c|c|c|c|c|c|c|c|c|c|c|c|}
\hline Year & Place & Authors & $\begin{array}{l}\text { Type } \\
\text { (S/ } \\
\text { M/A) }\end{array}$ & $\begin{array}{l}\text { Size: } \\
\geq 5 \\
\mathrm{~cm}\end{array}$ & $\begin{array}{l}\text { Size: } \\
5-10 \\
\text { cm }\end{array}$ & $\begin{array}{c}\text { Size: } \\
\geq 10 \\
\mathrm{~cm}\end{array}$ & $\begin{array}{c}\text { Number } \\
\text { of } \\
\text { patients } \\
(n)\end{array}$ & $\begin{array}{c}\text { 1-year } \\
\text { survival } \\
(\%)\end{array}$ & $\begin{array}{c}\text { 3-year } \\
\text { survival } \\
\text { (\%) }\end{array}$ & $\begin{array}{l}5 \text {-year } \\
\text { survival } \\
\text { (\%) }\end{array}$ & $\begin{array}{c}\text { Median } \\
\text { survival } \\
\text { (months) }\end{array}$ & $\begin{array}{c}\text { Post- } \\
\text { operative } \\
\text { mortality } \\
(\%)\end{array}$ & $\begin{array}{c}\text { Recruit- } \\
\text { ment } \\
\text { year }\end{array}$ \\
\hline 2007 & South Korea & Cho et al. ${ }^{[5]}$ & $\mathrm{S}$ & - & 61 & - & 61 & 85.0 & 59.0 & 52.9 & - & 1.6 & 1998-2001 \\
\hline 2007 & South Korea & Lee et $a / .^{[6]}$ & A & - & - & 100 & 100 & 66.0 & 44.0 & 31.0 & - & 2.0 & $1997-2003$ \\
\hline 2007 & Singapore & Pandey et al. ${ }^{[7]}$ & A & - & - & 166 & 166 & - & - & 28.6 & 20.0 & 3.0 & $1995-2006$ \\
\hline 2007 & Canada & Shah et al. ${ }^{[8]}$ & A & - & - & 24 & 24 & - & - & 54.0 & - & 8.3 & $1993-2004$ \\
\hline 2007 & UK & Young et $a{ }^{[9]}$ & A & - & 42 & - & 42 & 70.0 & 45.0 & 45.0 & - & 7.0 & $1994-2006$ \\
\hline 2008 & Japan & Shimada et $a l_{.}^{[10]}$ & A & - & - & 85 & 85 & - & - & 31.5 & 27.6 & 1.2 & $1988-2004$ \\
\hline 2008 & France & Chirica et al. ${ }^{[11]}$ & A & 20 & - & - & 20 & 73.0 & 56.0 & 45.0 & - & - & $1998-2004$ \\
\hline 2008 & Japan & Taniai et al. ${ }^{[12]}$ & A & - & - & 29 & 29 & - & 33.6 & 33.6 & - & 6.9 & $1987-2006$ \\
\hline 2008 & Taiwan & Wang et al. ${ }^{[13]}$ & A & 58 & - & - & 58 & 58.0 & 32.0 & 22.0 & - & - & $1990-2006$ \\
\hline 2008 & Taiwan & Wang et al. ${ }^{[14]}$ & A & 243 & - & - & 243 & 81.5 & 64.4 & 50.5 & 60.4 & - & $1986-2002$ \\
\hline 2009 & Australia & Ng et al. ${ }^{[15]}$ & A & - & - & 44 & 44 & 66.4 & 38.1 & 27.8 & 21.5 & - & $1990-2008$ \\
\hline 2009 & China & Yang et al. ${ }^{[16]}$ & A & 260 & - & 0 & 260 & 87.0 & 55.5 & 38.2 & 45.5 & 2.3 & $1992-2002$ \\
\hline 2009 & Korea & Choi et al..$^{[17]}$ & A & - & - & 50 & 50 & 70.0 & 50.2 & 40.2 & - & - & $1996-2006$ \\
\hline 2009 & Taiwan & Ho et al. ${ }^{[18]}$ & A & 294 & - & - & 294 & 77.4 & 51.9 & 36.6 & 37.9 & - & $1981-2000$ \\
\hline 2010 & Greece & Delis et al. ${ }^{[19]}$ & A & 66 & - & - & 66 & 69.0 & 37.0 & 32.0 & - & - & $2002-2008$ \\
\hline 2010 & Taiwan & Lin et $a l^{[20]}$ & A & 93 & - & - & 93 & 83.0 & 49.0 & - & 27.6 & 5.4 & 2001-2007 \\
\hline 2010 & Italy & Ramacciato et al. ${ }^{[21]}$ & M & 20 & - & - & 20 & - & - & 33.6 & - & - & $2000-2006$ \\
\hline 2010 & Italy & Ramacciato et al. ${ }^{[21]}$ & $\mathrm{s}$ & 31 & - & - & 31 & - & - & 56.1 & - & - & $2000-2006$ \\
\hline 2010 & USA & Schiffman et al. ${ }^{[22]}$ & A & 78 & - & - & 78 & - & - & 20.0 & - & - & 1999-2005 \\
\hline 2010 & China & Wang et al ${ }^{[23]}$ & A & - & 189 & - & 189 & 70.0 & 51.2 & 36.5 & - & 7.5 & $1991-2004$ \\
\hline 2011 & Japan & Yamashita et al. ${ }^{[24]}$ & A & 0 & - & 53 & 53 & 74.0 & 43.0 & 35.0 & - & 3.8 & $1995-2007$ \\
\hline 2011 & China & Luo et al. ${ }^{[26]}$ & A & 85 & - & 0 & 85 & 70.6 & 35.3 & 23.9 & - & 2.4 & $2004-2006$ \\
\hline 2011 & China & Zhou et al. ${ }^{[27]}$ & S & 85 & - & - & 85 & 93.8 & 56.2 & 47.0 & - & - & 1995-2002 \\
\hline 2012 & Italy & Ruzzenente et al. ${ }^{[25]}$ & S & 0 & 13 & - & 13 & 76.9 & 68.4 & 68.4 & - & 0.0 & $1995-2009$ \\
\hline 2012 & Taiwan & Chang et al. ${ }^{[28]}$ & A & 478 & - & & - & 74.6 & 51.8 & 40.7 & - & 2.7 & $1991-2006$ \\
\hline 2012 & Serbia & Galun et al. ${ }^{[29]}$ & A & 32 & - & - & 32 & - & - & - & 26.0 & 0.0 & $2001-2008$ \\
\hline 2012 & Taiwan & Huang et al. ${ }^{[30]}$ & A & - & - & 74 & 74 & 61.9 & 39.4 & 28.9 & 20.4 & - & $2001-2005$ \\
\hline 2012 & USA & Shrager et al. ${ }^{[31]}$ & A & - & - & 130 & 130 & 56.9 & 30.3 & 18.8 & 17.0 & $\begin{array}{l}6.9 \text { before } \\
2002 \\
2.3 \text { after } \\
2002\end{array}$ & 1992-2010 \\
\hline 2013 & Switzerland & Allemann et $a l_{.}^{[32]}$ & A & - & - & 22 & 22 & - & - & 45.0 & 27.0 & 0.0 & $1997-2009$ \\
\hline 2013 & Japan & Ariizumi et al. ${ }^{[33]}$ & A & - & - & 177 & 177 & 61.0 & 46.0 & 42.0 & 38.5 & - & $1990-2008$ \\
\hline 2014 & China & Yin et al. ${ }^{[34]}$ & A & 88 & - & - & 88 & 76.1 & 51.5 & & 41.0 & 1.1 & $2008-2010$ \\
\hline 2015 & Taiwan & Chan et $a I_{.}^{[35]}$ & A & - & - & 54 & 54 & 78.5 & 61.4 & 54.2 & - & - & $2005-2010$ \\
\hline 2016 & Taiwan & Chang et $a !_{.[36]}$ & A & - & 2306 & - & 2306 & 82.1 & - & 50.8 & - & - & $2002-2010$ \\
\hline 2016 & Taiwan & Chang et $a l .{ }^{[36]}$ & A & - & - & 912 & 912 & 68.5 & - & 35.0 & - & - & $2002-2010$ \\
\hline 2016 & Taiwan & Liu et $a l_{.}^{[37]}$ & A & 224 & - & - & 224 & 88.0 & 76.0 & 63.0 & - & - & - \\
\hline 2016 & China & Zhao et al. ${ }^{[38]}$ & A & 82 & - & - & 82 & 77.0 & 56.0 & 43.0 & - & - & 2005-2011 \\
\hline 2017 & South Korea & Jin et al. ${ }^{[39]}$ & $\mathrm{s}$ & 206 & - & - & 206 & 89.3 & 67.4 & 58.0 & - & - & $2008-2010$ \\
\hline
\end{tabular}

A: studies consider large tumors $(\geq 5 \mathrm{~cm}$ ) with or without multifocal tumors as one single population group; S: studies only consider solitary large tumors; M: studies only consider multifocal tumors, of which size can be $\leq 5 \mathrm{~cm}$

the 90's. But high-quality evidences only came in 2002, when two randomized controlled trials (RCTs) demonstrated the improvement in outcomes for patients with unresectable HCC when treated with TACE compared to conservative management ${ }^{[6,67]}$. Subsequent meta-analysis involving 7 RCTs also demonstrated an improvement in 2-year survival rate [odds ratio 0.53; 95\% confidence interval (CI): 0.32-0.89; $P=0.017$ ) ${ }^{[68]}$. Although this meta-analysis was later criticized for being small scale, using heterogeneous study population, and employing non-standardized TACE techniques and materials, many subsequent studies consistently reproduced the positive effects that TACE brought about in treating unresectable high-burden $\mathrm{HCC}^{[20,26,34,37,39,56,69-71]}[$ Table 6].

For high-burden HCC treated with TACE, the median 1-, 3- and 5-year overall survival rates were 68.4\%, $42.1 \%$ and $31.1 \%$ [Table 7]. In the case of solitary large $(\geq 5 \mathrm{~cm})$ HCC, the median 1-, 3-, and 5-year overall 
Table 2. Summary of median overall survival of large/multifocal high-burden hepatocellular carcinoma treated with surgery

\begin{tabular}{lcccc}
\hline & Solitary large tumor & $\begin{array}{c}\text { Moderately-large/multifocal } \\
(\geq \mathbf{5} \mathbf{~ c m} \text { and }<\mathbf{1 0} \mathbf{~ c m})\end{array}$ & $\begin{array}{c}\text { Huge/multifocal } \\
(\geq \mathbf{1 0} \mathbf{~ c m})\end{array}$ & Overall \\
\hline 1-year survival (\%) & 87.2 & 73.0 & 70.0 & 74.3 \\
3-year survival (\%) & 63.2 & 55.1 & 45.0 & 51.2 \\
5-year survival (\%) & 56.1 & 50.8 & 36.0 & 39.2 \\
\hline
\end{tabular}

Table 3. Recent studies on the efficacy of surgical resection in the management of high-burden hepatocellular carcinoma with portal vein invasion

\begin{tabular}{|c|c|c|c|c|c|c|c|c|c|c|c|}
\hline Year & Place & Authors & $\begin{array}{l}\text { Type } \\
\text { (S/A) }\end{array}$ & $\begin{array}{l}\text { Size: } \\
\geq 5 \mathrm{~cm}\end{array}$ & $\begin{array}{c}\text { Size: } \\
\text { 5-10 } \\
\text { cm }\end{array}$ & $\begin{array}{l}\text { Number of } \\
\text { patients }(n)\end{array}$ & $\begin{array}{c}\text { 1-year } \\
\text { survival } \\
\text { (\%) }\end{array}$ & $\begin{array}{c}\text { 3-year } \\
\text { survival } \\
\text { (\%) }\end{array}$ & $\begin{array}{c}\text { 5-year } \\
\text { survival } \\
(\%)\end{array}$ & $\begin{array}{l}\text { Median } \\
\text { survival } \\
\text { (months) }\end{array}$ & $\begin{array}{c}\text { Recruitment } \\
\text { year }\end{array}$ \\
\hline 2010 & Taiwan & Lin et al. ${ }^{[20]}$ & A & 78 & - & 78 & 39 & 2 & - & 15.8 & $2001-2007$ \\
\hline 2011 & China & Luo et al. ${ }^{[6]}$ & A & - & 83 & 83 & 67.2 & 26 & 18.9 & 19.5 & 2004-2006 \\
\hline 2014 & China & Yin et al. ${ }^{[34]}$ & A & - & 85 & 85 & 51.8 & 18.1 & - & 14 & $2008-2010$ \\
\hline 2014 & China & Jianyong et $a{ }^{[69]}$ & S & 190 & - & 190 & 87.9 & 76.3 & 57.9 & - & $2002-2008$ \\
\hline 2014 & China & Jianyong et $a l^{[69]}$ & A & 139 & - & 490 & 68.4 & 46 & 40.8 & - & $2002-2008$ \\
\hline 2015 & South Korea & Lee et $\left.a\right|^{[70]}$ & S & 68 & - & 68 & 89.8 & 72.8 & 49.6 & - & - \\
\hline 2016 & Japan & Kudo et al. ${ }^{[56]}$ & A & - & - & 1576 & 82.2 & 40.2 & 21.1 & - & $1997-2006$ \\
\hline 2016 & Taiwan & Liu et al. ${ }^{[37]}$ & S & 229 & - & 229 & 74 & 44 & 35 & - & - \\
\hline 2017 & South Korea & Jin et $a{ }^{[39]}$ & A & 489 & - & 489 & 67.7 & 38.2 & 27.2 & - & $2003-2010$ \\
\hline 2017 & Japan & Nouso et al. ${ }^{[71]}$ & $\mathrm{A}$ & 76 & - & 76 & - & 47.3 & 21.4 & 72 & 2001-2015 \\
\hline
\end{tabular}

A: studies consider large tumors ( $\geq 5 \mathrm{~cm}$ ) with or without multifocal tumors as one single population group; S: studies only consider solitary large tumors

Table 4. Classification of portal vein invasion

\begin{tabular}{|c|c|c|c|}
\hline \multicolumn{4}{|c|}{ Degree of invasion } \\
\hline \multicolumn{4}{|c|}{ VpO: no evidence of tumor thrombus invasion } \\
\hline \multicolumn{4}{|c|}{ Vp1: tumor thrombus distal to but not in the second-order branches } \\
\hline \multicolumn{4}{|c|}{ Vp2: tumor thrombus in the second-order branches } \\
\hline \multicolumn{4}{|c|}{ Vp3: tumor thrombus in the first-order branches } \\
\hline \multicolumn{4}{|c|}{ Vp4: tumor thrombus in the main trunk or contralateral or both } \\
\hline & Vp1 and Vp2 & Vp3 and Vp4 & Overall \\
\hline 1 -year survival (\%) & 69.1 & 52.8 & 61.0 \\
\hline 3-year survival (\%) & 42.2 & 23.4 & 32.9 \\
\hline 5-year survival (\%) & 38.7 & 14.6 & 27.0 \\
\hline
\end{tabular}

survival rates were higher: $87.9 \%, 72.8 \%$, and $49.6 \%$. In this group of high-burden HCC, TACE appeared to be inferior to surgical resection in prolonging survival. However, if we focus on solitary large HCC $(\geq 5 \mathrm{~cm})$ only, TACE appeared to outperform surgical resection [Table 7]. Therefore, it appears that surgery should be the choice of treatment when the tumor is "resectable", while TACE could be considered in the case of solitary large tumor.

TACE is commonly considered contraindicated in HCC with portal vein invasion due to the potential risk of acute liver failure resulting from post-TACE ischemia, as the normal liver parenchymal blood supply from the portal vein is already compromised. However, this contraindication has not been validated in large trials. On the contrary, a number of small retrospective studies have shown that TACE could be performed safely in patients with portal vein tumor thrombus (PVTT), provided that there was adequate liver reserve and the establishment of collateral blood circulation around the obstructed PVTT was sufficient ${ }^{[72,73]}$. 
Table 6. Recent studies on the efficacy of transarterial chemoembolization in the management of high-burden hepatocellular carcinoma

\begin{tabular}{|c|c|c|c|c|c|c|c|c|c|}
\hline Year & Place & Authors & $\begin{array}{l}\text { Vascular } \\
\text { invasion }\end{array}$ & $\begin{array}{c}\text { Number } \\
\text { of } \\
\text { patients } \\
(n)\end{array}$ & $\begin{array}{c}\text { 1-year } \\
\text { survival } \\
(\%)\end{array}$ & $\begin{array}{c}\text { 3-year } \\
\text { survival } \\
(\%)\end{array}$ & $\begin{array}{c}\text { 5-year } \\
\text { survival } \\
(\%)\end{array}$ & $\begin{array}{c}\text { Median } \\
\text { survival } \\
\text { (months) }\end{array}$ & $\begin{array}{c}\text { Recruitment } \\
\text { year }\end{array}$ \\
\hline 2009 & Japan & Ban et $\left.a\right|_{.} ^{[42]}$ & Vp3 and Vp4 & 45 & 69.6 & 37.4 & 22.4 & 20 & $1992-2008$ \\
\hline 2010 & China & Shi et al. ${ }^{[53]}$ & Vp1 and Vp2 & 139 & 52.1 & 25.1 & - & - & $2001-2003$ \\
\hline 2010 & China & Shi et al. ${ }^{[53]}$ & Vp3 & 169 & 38.2 & 17.7 & - & - & $2001-2003$ \\
\hline 2010 & China & Shi et al. ${ }^{[53]}$ & Vp4 & 78 & 24.7 & 3.6 & - & - & $2001-2003$ \\
\hline 2012 & Taiwan & Chang et $a l^{[28]}$ & - & 160 & 57.6 & 33.8 & 29.1 & - & 1991-2006 \\
\hline 2012 & China & Peng et al. ${ }^{[43]}$ & All types & 201 & 42 & 14.1 & 11.1 & 20 & $2002-2007$ \\
\hline 2012 & China & Chen et al. ${ }^{[50]}$ & All types & 88 & 31.1 & 15.2 & - & 9 & $2006-2008$ \\
\hline 2012 & Japan & Matono et al. ${ }^{[52]}$ & $\mathrm{Vp} 3$ and $\mathrm{Vp} 4$ & 29 & 62.1 & 24.1 & 17.2 & 16.6 & $1985-2005$ \\
\hline 2013 & USA & Roayaie et al. ${ }^{[46]}$ & All types & 165 & - & - & 14 & 13.1 & $1992-2010$ \\
\hline 2013 & China & Tang et al. ${ }^{[54]}$ & All types & 186 & 40.1 & 13.6 & - & 10 & $2006-2008$ \\
\hline 2013 & $\begin{array}{l}\text { France, Italy, Japan, } \\
\text { Argentina, USA }\end{array}$ & Torzilli et al. ${ }^{[55]}$ & All types & 297 & 76 & 49 & 38 & - & 1990-2009 \\
\hline 2014 & Taiwan & Liu et al. ${ }^{[48]}$ & Vp1 to Vp3 & 247 & 85 & 68 & 61 & 64 & 2002-2012 \\
\hline 2014 & Hong Kong & Chok et al. ${ }^{[57]}$ & Vp3 & 71 & 45.8 & 22.7 & 11.2 & 10.9 & $1989-2010$ \\
\hline 2015 & Japan & Kojima et $a l .{ }^{[44]}$ & $\mathrm{Vp} 3$ and $\mathrm{Vp} 4$ & 25 & 68 & 32 & 12 & 21.5 & $2001-2010$ \\
\hline 2016 & Japan & Kokudo et al. ${ }^{[45]}$ & All types & 1877 & 74.8 & 49.1 & 39.1 & 34 & 2000-2007 \\
\hline 2016 & Korea & Lee et $a{ }^{[47]}$ & Vp1 to Vp3 & 40 & - & - & - & 19.9 & $2000-2011$ \\
\hline 2016 & China & Zheng et al. ${ }^{[49]}$ & All types & 96 & 86.5 & 60.4 & 33.3 & - & $2000-2008$ \\
\hline 2016 & China & Li et al. ${ }^{[51]}$ & Vp4 & 50 & 35.6 & 0 & 0 & - & $2010-2013$ \\
\hline 2016 & China & Zhang et al. ${ }^{[58]}$ & Vp1 to Vp3 & 113 & 68.9 & 34.3 & 30.8 & 18.2 & 2005-2012 \\
\hline 2016 & Japan & Kudo et $a l^{[56]}$ & $\mathrm{Vp} 3$ and $\mathrm{Vp} 4$ & 852 & 59.8 & 34.3 & 25 & - & $1996-2007$ \\
\hline 2016 & Japan & Kudo et $a l^{[56]}$ & Vp2 & 714 & 69.1 & 42.2 & 29.2 & - & $1996-2007$ \\
\hline 2016 & Japan & Kudo et al. ${ }^{[56]}$ & Vp1 & 1908 & 84.9 & 62.4 & 48.2 & - & 1996-2007 \\
\hline
\end{tabular}

Table 7. Comparison of median overall survival of high-burden HCC treated with surgery and TACE

\begin{tabular}{lcccc}
\hline & Solitary large HCC (surgery) & Solitary large HCC (TACE) & Overall (surgery) & Overall (TACE) \\
\hline 1-year survival (\%) & 87.2 & 87.9 & 74.3 & 68.4 \\
3-year survival (\%) & 63.2 & 72.8 & 51.2 & 42.1 \\
5-year survival (\%) & 56.1 & 49.6 & 39.2 & 31.1 \\
\hline
\end{tabular}

HCC: hepatocellular carcinoma; TACE: transarterial chemoembolization

A small number of studies have explored the possibility of TACE as a palliative treatment in high-burden HCC with portal vein invasion ${ }^{[43,48,49,74-78]}$ [Table 8]. The median 1-year overall survival rate was $50.5 \%$. Even fewer studies have reported the median 3-year overall survival rate, likely due to the poor prognosis associated with portal vein invasion. No study thus far has compared difference in survival rate between segmental branches involvements (Vp1 and Vp2) and 1st branch or main trunk involvement (Vp3 and Vp4).

It is worth noting that many studies included in this review used conventional TACE (cTACE). However, drug-eluting bead TACE (DEB-TACE), since its introduction in 2006, was believed to be superior to cTACE. It has been demonstrated to have a lower toxicity profile compared to $\mathrm{CTACE}^{[79]}$. However, studies so far failed to prove its ability to consistently prolong survival ${ }^{[79-84]}$. Moreover, as a relatively new agent, only a paucity of studies has looked at its effect on high-burden HCC, particularly those with portal vein invasion. More studies are needed for this particular population of patients.

\section{Transarterial radioembolization}

Although TACE has been shown to be an effective therapy for high-burden unresectable HCC, it is associated with substantial systemic toxicities. In a Cochrane review in 2011, post-embolization syndrome, with clinical manifestations of transient fever, abdominal pain and elevated transaminases, was reported to occur in up to $80 \%$ of the patients receiving $\mathrm{TACE}^{[85]}$. Other serious adverse events, albeit uncommon, include acute renal failure, ascites, encephalopathy and transient liver failure ${ }^{[79]}$. 
Table 8. Recent studies on the efficacy of transarterial chemoembolization in the management of high-burden hepatocellular carcinoma with portal vein invasion

\begin{tabular}{|c|c|c|c|c|c|c|c|c|c|}
\hline Year & Place & Authors & $\begin{array}{l}\text { Vascular } \\
\text { invasion }\end{array}$ & $\begin{array}{l}\text { Number of } \\
\text { patients }(n)\end{array}$ & $\begin{array}{c}\text { 1-year } \\
\text { survival } \\
(\%)\end{array}$ & $\begin{array}{c}\text { 3-year } \\
\text { survival } \\
(\%)\end{array}$ & $\begin{array}{c}\text { 5-year } \\
\text { survival } \\
(\%)\end{array}$ & $\begin{array}{l}\text { Median } \\
\text { survival } \\
\text { (months) }\end{array}$ & Recruitment year \\
\hline 2012 & China & Niu et $\left.a\right|_{.} ^{[78]}$ & All types & 115 & 27.8 & - & - & 8.67 & $2007-2010$ \\
\hline 2012 & China & Peng et al. ${ }^{[43]}$ & All types & 402 & 37.8 & 7.3 & 0.5 & 13.1 & 2002-2007 \\
\hline 2014 & India & Ajit et al. ${ }^{[74]}$ & All types & 17 & 47.0 & - & - & 10 & $2011-2013$ \\
\hline 2014 & Taiwan & Chern et $a l^{[75]}$ & $\mathrm{Vp} 3$ and $V p 4$ & 50.0 & 54.0 & 10.0 & - & 6.2 & $2006-2012$ \\
\hline 2014 & Taiwan & Liu et $a{ }^{[488]}$ & Vp1 to Vp3 & 181 & 60 & 42 & 33 & 32 & 2002-2012 \\
\hline 2016 & China & Zheng et al. ${ }^{[49]}$ & All types & 134 & 77.6 & 47.6 & 20.9 & - & $2000-2008$ \\
\hline 2017 & Korea & Choi et al. ${ }^{[76]}$ & Vp1 and $V p 2$ & 50 & - & - & - & 9.4 & 2003-2012 \\
\hline 2017 & USA & Gorodetski et al. ${ }^{[77]}$ & All types & 133 & - & - & - & 4.53 & 2006-2013 \\
\hline
\end{tabular}

In view of this, much effort has been made to devise new intra-arterial therapies with less systemic toxicities. In recent years, TARE has become an alternative to TACE in treating high-burden HCC. TARE is an intraarterial therapy that involves the delivery of microspheres containing yttrium-90 into the hepatic arteries. TARE asserts the main effect through the internal radiotherapy delivered by Y-90, a radioactive substance, which causes necrosis of the tumor.

As data is lacking for TARE, much of the evidences came from retrospective studies of experimental intent ${ }^{[86-94]}$. These studies either looked into the efficacy of TARE by itself, or made a comparison with TACE, the gold standard for unresectable high-burden HCC. The median survival rate for high-burden HCC treated with TARE was 15.0 (range: 11.5-20.0) months, with a response rate of $41.5 \%$ by the mRECIST criteria [Table 9]. In those studies comparing TARE and TACE retrospectively, they were not able to show any difference between survival ${ }^{[88,93,94]}$. However, TARE was found to be associated with longer time-toprogression, less toxicity and shorter hospital stay comparing with TACE, suggesting that it may be a more favorable treatment modality for unresectable high-burden HCC. As for large solitary tumor or multifocal tumors, where TACE is known to be ineffective due to the severe adverse effects ${ }^{[95]}$, TARE could also be a preferred alternative.

Despite its better safety profile, TARE is not yet considered standard treatment by a number of clinicians. Apart from the lack of high quality evidence to support its efficacy on high-burden HCC, TARE is an expensive procedure and it requires specialized training for implementation ${ }^{[96]}$. Given the promising results from retrospective studies, more clinical trials are needed in the coming years to formally evaluate its effectiveness and safety profile, and its potential to replace TACE's role in the treatment of unresectable highburden HCC.

\section{Radiotherapy}

External radiation historically had limited role in the management of HCC. This is mainly due to the radiotoxicity on the non-tumorous surrounding tissue. Radiation induced liver disease (RILD) is a common side effect of radiotherapy for liver cancer. In the RTOG 84-05 dose escalation study, among the patients receiving whole liver RT of 33 Gy in $1.5 \mathrm{~Gy}$, around $10 \%$ of patients experienced RILD ${ }^{[97]}$.

However, with the recent advancements in irradiation technique, treatment modalities such as $3 \mathrm{D}$-conformal RT (3D-CRT) and stereotactic body radiation (SBRT) have emerged as feasible options to treat high-burden HCC. With these technologies, high dose radiation can be effectively delivered to a precise area, sparing the surrounding normal liver tissue. This is particularly important for those patients with high-burden HCC who are not eligible for surgery or local therapies due to suboptimal liver reserve, anatomical locations of the tumors or poor performance status. Therefore, radiotherapy has become an attractive alternative in those cases. 
Table 9. Recent studies on the efficacy of transarterial chemoembolization in the management of high-burden hepatocellular carcinoma

\begin{tabular}{|c|c|c|c|c|c|c|c|c|}
\hline Year & Place & Authors & $\begin{array}{l}\text { Number of } \\
\text { patients }(n)\end{array}$ & Evaluation criteria & $\begin{array}{c}\text { Time to } \\
\text { progression } \\
\text { (months) }\end{array}$ & $\begin{array}{c}\text { Median } \\
\text { survival } \\
\text { (months) }\end{array}$ & $\begin{array}{c}\text { Response } \\
\text { rate (\%) }\end{array}$ & $\begin{array}{c}\text { Recruitment } \\
\text { year }\end{array}$ \\
\hline 2010 & European & Hilgard et al. ${ }^{[86]}$ & 108 & EASL & 10 & 16.4 & 40 & - \\
\hline 2010 & USA & Salem et $a / .{ }^{[89]}$ & 291 & WHO & 7.9 & $\begin{array}{l}\text { BCLC-B: } 13.3 \\
\text { BCLC-C: } 6.0\end{array}$ & 42 & - \\
\hline 2010 & USA & Carr et al. ${ }^{[90]}$ & 99 & WHO & 7.9 & 11.5 & 41 & - \\
\hline 2011 & European & Sangro et al. ${ }^{[87]}$ & 325 & - & - & 12.8 & - & - \\
\hline 2011 & USA & Salem et $a .^{[88]}$ & 123 & WHO & 13.3 & 20.5 & 49 & 1999-2008 \\
\hline 2013 & Italy & Mazzaferro et al. ${ }^{[92]}$ & 52 & RECIST/WHO/EASL & 11 & 15 & 40.4 & 2007-2009 \\
\hline 2013 & USA & Moreno-Luna et al. ${ }^{[93]}$ & 61 & mRECIST & - & 15 & 51 & $2005-2008$ \\
\hline 2015 & Korea & Kim et al. ${ }^{[91]}$ & 40 & mRECIST & 18 & - & 63.8 & 2008-2010 \\
\hline 2015 & Germany & El Fouly et al. ${ }^{[94]}$ & 44 & mRECIST & 13.3 & 16.4 & $37 \%$ & 2009-2011 \\
\hline
\end{tabular}

Multiple retrospective studies, albeit small scale, have demonstrated the efficacy and safety of 3D-CRT and SBRT in treating high-burden HCC ${ }^{[54,98-109]}$ [Table 10]. The response rates of these two techniques ranged from $22 \%$ to $76.2 \%$, and the 1-year survival rates ranged from $16.7 \%$ to $55 \%$. Given that this group of patients are expected to be in much poorer conditions than those amenable to surgery or intra-arterial embolization, the results achieved are encouraging. However, there has been no direct comparison between 3D-CRT and SBRT, and variability of results was wide. Therefore, larger scale studies are needed to establish the role of RT in managing high-burden HCC.

\section{Systemic therapy}

Our definition of high-burden HCC excludes patients with extrahepatic metastasis, for whom systemic therapy would be the preferred option. However, even for patients without extrahepatic metastasis, when all the other treatment modalities fail, systemic therapy would be the last resort. In this section, we will discuss the systemic therapies which are applicable to high-burden HCC [Table 11].

\section{Targeted therapy}

Traditional systemic therapy has never been favored for a long time in treating advanced HCC due to its poor efficacy and the general cytotoxicity which preclude its application in this group of frail patients. It was only since 2008 , we celebrated the introduction of sorafenib, a multikinase inhibitor, which has been demonstrated to prolong survival in two large randomized controlled trials ${ }^{[110,111]}$. In the SHARP trial, the median survival of patients with advanced disease treated with sorafenib was 10.7 months, vs. 7.9 months in those who received placebo (harzard ratio 0.69, 95\%CI: 0.55-0.87; $P<0.001$ ). The Asia-Pacific trial was able to replicate similar findings, suggesting sorafenib to be an effective drug across patients with advanced HCC regardless of etiology and ethnicity.

Since then, much effort has been spent on exploring newer targeted therapies. Unfortunately, none of the trials in the past decade was able to identify a better targeted agent in treating advanced HCC ${ }^{[112-116]}$. Only recently in 2017, Bruix et al. ${ }^{[117]}$ in the RESORCE trial has found regorafenib, an oral multikinase inhibitor that blocks angiogenesis, oncogenesis, metastasis and tumor immunity, to be an effective second line treatment for patients who have failed sorafenib. The median survival rate for patients on regorafenib after sorafenib use was 10.6 months compared to 7.8 months in the placebo group. The side effects associated with regorafenib use are typical of multi-kinase inhibitors, including hypertension, hand-foot skin reaction and gastrointestinal disturbances. Rate of drug-related adverse events leading to discontinuation of regorafenib is similar to that of sorafenib $(10 \% v s .11 \%)^{[110,117]}$. Regorafenib thus has become the only clinically proven second line systemic drug available in sorafenib-resistant cases thus far.

\section{Immunotherapy}

Although targeted therapy seems to have hit a roadblock, other routes of development have been ongoing. Immunotherapy is the most notable one. Ever since the introduction of immune checkpoint inhibitors 
Table 10. Recent studies on the efficacy of radiotherapy in the management of high-burden hepatocellular carcinoma

\begin{tabular}{|c|c|c|c|c|c|c|c|c|c|c|c|}
\hline Year & Place & Authors & Method & $\begin{array}{c}\text { Number } \\
\text { of } \\
\text { patients } \\
(n)\end{array}$ & $\begin{array}{l}\text { Dose/ } \\
\text { fraction }\end{array}$ & $\begin{array}{c}\text { Evaluation } \\
\text { criteria }\end{array}$ & $\begin{array}{c}\text { 1-year } \\
\text { survival } \\
(\%)\end{array}$ & $\begin{array}{c}\text { 3-year } \\
\text { survival } \\
(\%)\end{array}$ & $\begin{array}{c}\text { Median } \\
\text { survival } \\
\text { (mos) }\end{array}$ & $\begin{array}{c}\text { Response } \\
\text { rate }(\%)\end{array}$ & $\begin{array}{l}\text { Recruit- } \\
\text { ment year }\end{array}$ \\
\hline 2007 & Japan & Toya et al. ${ }^{[103]}$ & 3DCRT & 38 & $\begin{array}{l}17.5-50.4 \\
\text { Gy; } 1.8-4 \\
\text { Gy/Fr }\end{array}$ & mRECIST & 39.4 & - & 9.6 & 44.7 & 1999-2005 \\
\hline 2009 & China & Huang et al.. ${ }^{[83]}$ & 3DCRT & 326 & $\begin{array}{l}60 \mathrm{~Gy} ; 2-3 \\
\mathrm{~Gy} / \mathrm{Fr}\end{array}$ & - & 16.7 & - & 3.8 & 25.2 & 1997-2005 \\
\hline 2010 & Korea & Ohet al. ${ }^{[104]}$ & TACE + 3DCRT & 40 & $\begin{array}{l}30-54 \mathrm{~Gy} \\
2.5-5 \mathrm{~Gy} / \\
\mathrm{Fr}\end{array}$ & - & 72 & - & 19 & 62.8 & 2006-2007 \\
\hline 2012 & Korea & Yoon et al. ${ }^{[108]}$ & TACE + 3DCRT & 412 & $\begin{array}{l}21-60 \mathrm{~Gy} ; \\
2-5 \mathrm{~Gy} / \mathrm{Fr}\end{array}$ & mRECIST & 42.5 & - & 10.6 & 28.1 & 2002-2008 \\
\hline 2013 & Canada & Bujold et $\left.a\right|^{[101]}$ & SBRT & 102 & $\begin{array}{l}30-54 \mathrm{~Gy} ; \\
6 \mathrm{~Gy} / \mathrm{Fr}\end{array}$ & mRECIST & 55 & - & 17 & 44 & $2004-2010$ \\
\hline 2013 & Korea & Bae et al. ${ }^{[99]}$ & SBRT & 35 & $\begin{array}{l}30-60 \mathrm{~Gy} ; \\
\text { 3-5 Gy/Fr }\end{array}$ & mRECIST & 52 & 21 & 14 & 41 & 2003-2011 \\
\hline 2013 & China & Tang et $a{ }^{[54]}$ & TACE + 3DCRT & 185 & $\begin{array}{l}\text { 30-52 Gy; } \\
\text { 3-4 Gy/Fr }\end{array}$ & - & 42.2 & 17.3 & 12.3 & - & 2006-2008 \\
\hline 2014 & Canada & Culleton et al..$^{[100]}$ & SBRT & 29 & $\begin{array}{l}19.7-46.8 \\
\mathrm{~Gy} ; 6 \mathrm{~Gy} / \\
\mathrm{Fr}\end{array}$ & mRECIST & 32.3 & - & 7.9 & - & 2004-2012 \\
\hline 2014 & Korea & Cho et $a{ }^{[105]}$ & TACE + 3DCRT & 67 & $\begin{array}{l}30-45 \mathrm{~Gy} ; \\
2-4.5 \mathrm{~Gy} / \\
\mathrm{Fr}\end{array}$ & - & - & - & 14.1 & - & 2007-2011 \\
\hline 2016 & Japan & Matsuo et al. ${ }^{[98]}$ & SBRT & 43 & $\begin{array}{l}45-55 \mathrm{~Gy} ; \\
10-15 \mathrm{~Gy} / \\
\mathrm{Fr}\end{array}$ & - & 49.3 & - & 11 & 67 & $2008-2013$ \\
\hline 2016 & Japan & Matsuo et al. ${ }^{[98]}$ & 3DCRT & 54 & $\begin{array}{l}45-50 \mathrm{~Gy} ; \\
15-25 \mathrm{~Gy} / \\
\mathrm{Fr}\end{array}$ & - & 29.3 & - & 6 & 46 & $2008-2013$ \\
\hline 2016 & Japan & Okazaki et al. ${ }^{[109]}$ & 3DCRT & 56 & $\begin{array}{l}22-50 \mathrm{~Gy} ; \\
2 \mathrm{~Gy} / \mathrm{Fr}\end{array}$ & mRECIST & - & - & 6.4 & 22 & 2007-2013 \\
\hline 2017 & Taiwan & Lo et al. ${ }^{[102]}$ & SBRT & 89 & $\begin{array}{l}25-60 \mathrm{~Gy} ; \\
4-6 \mathrm{~Gy} / \mathrm{Fr}\end{array}$ & - & 45.9 & 24.3 & 10.9 & 76.2 & 2007-2015 \\
\hline
\end{tabular}

TACE: transarterial chemoembolization

to cancer treatment, results of clinical studies have far exceeded expectation. In 2013, the journal Science has selected cancer immunotherapy as the Breakthrough of the Year ${ }^{[118]}$. Cancer immunotherapy has been shown to be effective in treating cancers in multiple tissue organs, most notably lung cancer, melanoma and renal-cell carcinoma ${ }^{[119-121]}$.

Latest studies have demonstrated promising results in the application of immunotherapy in treating advanced $\mathrm{HCC}^{[122,123]}$. Nivolumab, a PD-1 inhibitor, has been shown to prolong survival in patients with advanced HCC unsuitable for surgery or other local therapies ${ }^{[123]}$. In an international phase $1 / 2$ trial (CheckMate040), nivolumab was demonstrated to have an objective response rate of $15 \%-20 \%$ in patients with advanced HCC, irrespective of line of therapy ${ }^{[123]}$. This was a significant improvement to the first-line sorafenib therapy, with a response rate of $2 \%-3 \%^{[110]}$, and the second-line regorafenib therapy, with a response rate of $7 \%{ }^{[117]}$. The overall 9 -month survival rate was $74 \%$, which showed a marked improvement compared to the median survival of 6 months for untreated advanced HCC.

Despite the relatively promising results shown in immunotherapy on HCC, studies so far conducted were relatively small scale. Larger scales are needed to evaluate the efficacy of immunotherapy on HCC.

\section{ETIOLOGICAL ADJUNCTIVE TREATMENT FOR HIGH-BURDEN HCC}

While we have discussed above the different treatment modalities available for high-burden HCC, it is also of paramount importance to control the underlying risk factors during treatment. By far, HBV and 
Table 11. Clinical trials on systemic therapy in the management of advanced HCC

\begin{tabular}{|c|c|c|c|c|c|c|c|c|}
\hline Drug name & Class & $\begin{array}{l}\text { Trial } \\
\text { name }\end{array}$ & Year & Authors & Phase & Case & Control & Result \\
\hline Sorafenib & $\begin{array}{l}\text { Oral multikinase } \\
\text { inhibitor }\end{array}$ & SHARP & 2008 & Llovet et $\left.a\right|^{[110]}$ & Phase 3 & 299 & 303 & $\begin{array}{l}\text { Median survival: } 10.7 \\
\text { (sorafenib) vs. } 7.9 \text { months } \\
\text { (placebo); } \\
P<0.001\end{array}$ \\
\hline Sorafenib & $\begin{array}{l}\text { Oral multikinase } \\
\text { inhibitor }\end{array}$ & Asia-Pacific & 2009 & Cheng et $a / .^{[111]}$ & Phase 3 & 150 & 76 & $\begin{array}{l}\text { Median survival: } 6.5 \text { (sorafenib) } \\
\text { vs. } 4.2 \text { months (placebo); } \\
P=0.014\end{array}$ \\
\hline Cabozantinib & $\begin{array}{l}\text { Oral multikinase } \\
\text { inhibitor }\end{array}$ & CELESTIAL & 2012 & Verslype et $a / .^{[134]}$ & Phase 2 & 41 & - & $\begin{array}{l}\text { Granted orphan drug status by } \\
\text { FDA }\end{array}$ \\
\hline Ramucirumab & $\begin{array}{l}\text { Anti-VEGF2 } \\
\text { monoclonal }\end{array}$ & REACH & 2015 & Zhu et al. ${ }^{[112]}$ & Phase 3 & 283 & 282 & $\begin{array}{l}\text { Median survival: } 9.2 \\
\text { (ramucirumab) vs. } 7.6 \text { months } \\
\text { (placebo); } P=0.14\end{array}$ \\
\hline Regorafenib & $\begin{array}{l}\text { Oral multikinase } \\
\text { inhibitor }\end{array}$ & RESORCE & 2017 & Bruix et al. ${ }^{[117]}$ & Phase 3 & 379 & 193 & $\begin{array}{l}\text { Median survival: } 10.6 \\
\text { (regorafenib) vs. } 7.8 \text { months } \\
\text { (placebo); } P<0.0001\end{array}$ \\
\hline Tivantinib & $\begin{array}{l}\text { Oral multikinase } \\
\text { inhibitor }\end{array}$ & JET-HCC & 2017 & Kobayashi et al. ${ }^{[135]}$ & Phase 3 & 134 & 61 & $\begin{array}{l}\text { Press release announced that } \\
\text { the METIV-HCC phase } 3 \text { study } \\
\text { did not meet its primary end } \\
\text { point of improving survival }\end{array}$ \\
\hline Lenvatinib & $\begin{array}{l}\text { Oral multikinase } \\
\text { inhibitor }\end{array}$ & REFLECT & 2017 & Cheng et $a / .^{[116]}$ & $\begin{array}{l}\text { Non- } \\
\text { inferior } \\
\text { study }\end{array}$ & 478 & $\begin{array}{l}476 \\
\text { (sorafenib) }\end{array}$ & $\begin{array}{l}\text { Median survival: } 13.6 \\
\text { (lenvatinib) vs. } 12.3 \text { months } \\
\text { (sorafenib) }\end{array}$ \\
\hline Ramucirumab & $\begin{array}{l}\text { Anti-VEGF2 } \\
\text { monoclonal }\end{array}$ & $\begin{array}{l}\text { REACH } \\
\text { (subgroup } \\
\text { analysis) }\end{array}$ & 2017 & Zhu et $\left.a\right|^{[112]}$ & Phase 3 & $\begin{array}{l}\mathrm{CP}-\mathrm{A} \text { and } \\
\text { baseline } \\
\text { AFP }>400 \\
\mathrm{ng} / \mathrm{mL}: 68 \\
\mathrm{CP}-\mathrm{B} \text { and } \\
\text { baseline } \\
\text { AFP }>400 \\
\mathrm{ng} / \mathrm{mL}: 52\end{array}$ & $\begin{array}{l}\mathrm{CP}-\mathrm{A} \text { and } \\
\text { baseline AFP } \\
>400 \mathrm{ng} / \mathrm{mL} \text { : } \\
83 \\
\mathrm{CP}-\mathrm{B} \text { and } \\
\text { baseline AFP } \\
>400 \mathrm{ng} / \mathrm{mL} \text { : } \\
48\end{array}$ & $\begin{array}{l}\text { Median survival: CP-A: } 8.6 \\
\text { (ramucirumab) vs. } 4.8 \text { months } \\
\text { (placebo); } P=0.01 \\
\text { Median survival: CP-B: } 5.7 \\
\text { (ramucirumab) vs. } 3.6 \text { months } \\
\text { (placebo); } P=0.04\end{array}$ \\
\hline Nivolumab & Immunotherapy & $\begin{array}{l}\text { CheckMate } \\
040\end{array}$ & 2017 & El-Khoueiry et al. ${ }^{[123]}$ & $\begin{array}{l}\text { Phase } \\
1 / 2\end{array}$ & $\begin{array}{l}\text { Dose } \\
\text { escalation } \\
\text { phase: } 48 \\
\text { Dose- } \\
\text { expansion } \\
\text { phase: } 214\end{array}$ & & $\begin{array}{l}\text { Response rate of } 83 \% \text { in } 6 \\
\text { months; } 74 \% \text { in } 9 \text { month in } \\
\text { dose expansion phase }\end{array}$ \\
\hline
\end{tabular}

AFP: alpha-fetoprotein; HCC: hepatocellular carcinoma

HCV infections are the most important risk factors for HCC. Together, they account for $80 \%$ of the HCC worldwide ${ }^{[124]}$. The use of antivirals not only reduces the incidence of HCC in viral carriers, it is also effective in reducing HCC recurrence and prolonging survival. This is because viral reactivation is a major complication of HCC treatment. Patients with high-burden HCC are particularly at risk of viral reactivation due to chronic immunosuppression, higher tumor load and poorer liver reserve. Uncontrolled viral reactivation may provoke acute hepatitis, fulminant liver failure and even death.

Evidence supporting the use of antivirals as adjunctive treatment of HCC has been reviewed elsewhere ${ }^{[125,126]}$. In general, antivirals should be administered prior to treatment of HCC once the patient is known to be a virus carrier. For HBV-related HCC, the benefit of antivirals is seen in patients treated by surgery ${ }^{[127]}$, $\mathrm{TACE}^{[128]}$ or radiotherapy ${ }^{[129]}$. For HCV-related HCC, evidence is available for older generation interferonbased antivirals that they reduce tumor recurrence ${ }^{[130,131]}$. On the contrary, the newer generation of antivirals, e.g. direct-acting antivirals (DAA), have been shown to increase the chance of HCC recurrence ${ }^{[132,133]}$. However, these studies had been criticized for being small scale, short duration of observation period and lacking a proper control group. Further studies thus are needed to elucidate the effectiveness of DAAs as adjunct in the treatment of HCV-related HCC.

\section{DISCUSSION AND CLOSING REMARKS}

Our definition of high-burden HCC focuses on the "grey zone" where tumors are neither metastasized nor localized enough to have an obvious choice of treatment modality. Though they carry a worse prognosis 
than the classically defined intermediate-stage HCC, if the optimal treatment can be chosen for this group of patients, the impact on their survival rates can be significant. Results from various retrospective and cohort studies in the past decade have been encouraging, providing strong support for multimodality treatment in the management of high-burden HCC.

In this review, we showed that surgical approach to high-burden HCC, if feasible, provides the highest median survival across all treatment modalities. Nonetheless, there has not been a large-scale RCT that quantified its positive effect in managing high-burden HCC in direct comparison with other treatment modalities.

In cases where surgical resection is not feasible, intra-arterial embolization is commonly adopted as an alternative treatment modality. Thus far, studies have not been able to demonstrate a significant difference in survival between the two available intra-arterial embolization options, TACE and TARE. Overall, TARE appears to be superior in terms of providing a better safety profile and associating with fewer adverse outcomes. Nonetheless, it is a novel method for HCC and expertise might only be available in selective tertiary centers.

Advancements in irradiation technique have enabled radiotherapy to emerge as another unconventional treatment option for high-burden HCC. Early results in 3D-CRT and SBRT have been promising but further evidences are needed to delineate their role in managing high-burden HCC.

Targeted therapy has been in a bottleneck for treating high-burden HCC since the introduction of sorafenib. Regorfanib, now being the second-line agent to sorafenib, is the only newer targeted agent thus far that has been proved effective in managing high-burden HCC. On the other side, breakthroughs have been made in immunotherapy in the past decade with promising results with nivorumab and other immunostimulating agents. Many RCTs are underway to further establish the role of immunotherapy in managing HCC and we expect more results to emerge in the next few years.

As majority of the HCCs are attributed from HBV or HCV infection, the use of antivirals as adjunctive treatment is also of paramount importance. It can effectively reduce HCC recurrence and prolong survival. Despite early studies regarding use of DAAs in the treatment of HCV-related HCC suggest higher tumor recurrence rate, those studies have been heavily criticized of poor design. Further studies are needed to elucidate the role of DAAs as an adjunctive treatment for HCV-related HCC.

In summary, high-burden HCC remains a difficult cancer entity to manage. Yet, multiple treatment options are available of which optimal selection can effectively prolong survival for this group of patients. Treatment modalities are evolving in the management of high-burden HCC and promising results from retrospective and cohort studies are plentiful. But high-quality studies are lacking. Larger scale controlled studies with more specific patient selection criteria are needed for various treatment modalities, to further assess and compare the benefits of these different options.

\section{DECLARATIONS}

\section{Authors' contributions}

Conceptualization: Chan LL, Chan SL

Literature search: Chan LL

First draft: Chan LL

Revision and final proofread: Chan LL, Chan SL

\section{Financial support and sponsorship}

None. 


\section{Conflicts of interest}

There are no conflicts of interest.

\section{Patient consent}

Not applicable.

\section{Ethics approval}

Not applicable.

\section{Copyright}

(c) The Author(s) 2018.

\section{REFERENCE}

1. McGuire S. World Cancer Report 2014. Geneva, Switzerland: World Health Organization, International Agency for Research on Cancer, WHO Press, 2015. Adv Nutr 2016;7:418-9.

2. Zhong JH, Rodriguez AC, Ke Y, Wang YY, Wang L, Li LQ. Hepatic resection as a safe and effective treatment for hepatocellular carcinoma involving a single large tumor, multiple tumors, or macrovascular invasion. Medicine (Baltimore) 2015;94:e396.

3. Chan SL, Chong CC, Chan AW, Poon DM, Chok KS. Management of hepatocellular carcinoma with portal vein tumor thrombosis: review and update at 2016. World J Gastroenterol 2016;22:7289-300.

4. Forner A, Gilabert M, Bruix J, Raoul JL. Treatment of intermediate-stage hepatocellular carcinoma. Nat Rev Clin Oncol 2014;11:525-35.

5. Cho YB, Lee KU, Lee HW, Cho EH, Yang SH, Cho JY, Yi NJ, Suh KS. Outcomes of hepatic resection for a single large hepatocellular carcinoma. World J Surg 2007;31:795-801.

6. Lee SG, Hwang S, Jung JP, Lee YJ, Kim KH, Ahn CS. Outcome of patients with huge hepatocellular carcinoma after primary resection and treatment of recurrent lesions. Br J Surg 2007;94:320-6.

7. Pandey D, Lee KH, Wai CT, Wagholikar G, Tan KC. Long term outcome and prognostic factors for large hepatocellular carcinoma $(10 \mathrm{~cm}$ or more) after surgical resection. Ann Surg Oncol 2007;14:2817-23.

8. Shah SA, Wei AC, Cleary SP, Yang I, McGilvray ID, Gallinger S, Grant DR, Greig PD. Prognosis and results after resection of very large (> or $=10 \mathrm{~cm}$ ) hepatocellular carcinoma. $J$ Gastrointest Surg 2007;11:589-95.

9. Young AL, Malik HZ, Abu-Hilal M, Guthrie JA, Wyatt J, Prasad KR, Toogood GJ, Lodge JP. Large hepatocellular carcinoma: time to stop preoperative biopsy. J Am Coll Surg 2007;205:453-62.

10. Shimada K, Sakamoto Y, Esaki M, Kosuge T. Role of a hepatectomy for the treatment of large hepatocellular carcinomas measuring $10 \mathrm{~cm}$ or larger in diameter. Langenbecks Arch Surg 2008;393:521-6.

11. Chirica M, Scatton O, Massault PP, Aloia T, Randone B, Dousset B, Legmann P, Soubrane O. Treatment of stage IVA hepatocellular carcinoma: should we reappraise the role of surgery? Arch Surg 2008;143:538-43; discussion 543.

12. Taniai N, Yoshida H, Tajiri T. Adaptation of hepatectomy for huge hepatocellular carcinoma. J Hepatobiliary Pancreat Surg 2008;15:410-6.

13. Wang BW, Mok KT, Liu SI, Chou NH, Tsai CC, Chen IS, Yeh MH, Chen YC. Is hepatectomy beneficial in the treatment of multinodular hepatocellular carcinoma? J Formos Med Assoc 2008;107:616-26.

14. Wang JH, Changchien CS, Hu TH, Lee CM, Kee KM, Lin CY, Chen CL, Chen TY, Huang YJ, Lu SN. The efficacy of treatment schedules according to Barcelona Clinic Liver Cancer staging for hepatocellular carcinoma - survival analysis of 3892 patients. Eur J Cancer 2008;44:1000-6.

15. Ng KM, Yan TD, Black D, Chu FC, Morris DL. Prognostic determinants for survival after resection/ablation of a large hepatocellular carcinoma. HPB (Oxford) 2009;11:311-20.

16. Yang LY, Fang F, Ou DP, Wu W, Zeng ZJ, Wu F. Solitary large hepatocellular carcinoma: a specific subtype of hepatocellular carcinoma with good outcome after hepatic resection. Ann Surg 2009;249:118-23.

17. Choi GH, Han DH, Kim DH, Choi SB, Kang CM, Kim KS, Choi JS, Park YN, Park JY, Kim DY, Han KH, Chon CY, Lee WJ. Outcome after curative resection for a huge $(>$ or $=10 \mathrm{~cm}$ ) hepatocellular carcinoma and prognostic significance of gross tumor classification. $\mathrm{Am} \mathrm{J}$ Surg 2009;198:693-701.

18. Ho MC, Huang GT, Tsang YM, Lee PH, Chen DS, Sheu JC, Chen CH. Liver resection improves the survival of patients with multiple hepatocellular carcinomas. Ann Surg Oncol 2009;16:848-55.

19. Delis SG, Bakoyiannis A, Tassopoulos N, Athanassiou K, Kelekis D, Madariaga J, Dervenis C. Hepatic resection for hepatocellular carcinoma exceeding Milan criteria. Surg Oncol 2010;19:200-7.

20. Lin CT, Hsu KF, Chen TW, Yu JC, Chan DC, Yu CY, Hsieh TY, Fan HL, Kuo SM, Chung KP, Hsieh CB. Comparing hepatic resection and transarterial chemoembolization for Barcelona Clinic Liver Cancer (BCLC) stage B hepatocellular carcinoma: change for treatment of choice? World J Surg 2010;34:2155-61.

21. Ramacciato G, Mercantini P, Petrucciani N, Ravaioli M, Cucchetti A, Del Gaudio M, Cescon M, Ziparo V, Pinna AD. Does surgical resection have a role in the treatment of large or multinodular hepatocellular carcinoma? Am Surg 2010;76:1189-97.

22. Schiffman SC, Woodall CE, Kooby DA, Martin RC, Staley CA, Egnatashvili V, McMasters KM, Scoggins CR. Factors associated with recurrence and survival following hepatectomy for large hepatocellular carcinoma: a multicenter analysis. J Surg Oncol 2010;101:105-10.

23. Wang J, Xu LB, Liu C, Pang HW, Chen YJ, Ou QJ. Prognostic factors and outcome of 438 Chinese patients with hepatocellular carcinoma 
underwent partial hepatectomy in a single center. World J Surg 2010;34:2434-41.

24. Yamashita Y, Taketomi A, Shirabe K, Aishima S, Tsuijita E, Morita K, Kayashima H, Maehara Y. Outcomes of hepatic resection for huge hepatocellular carcinoma ( $>/=10 \mathrm{~cm}$ in diameter). J Surg Oncol 2011;104:292-8.

25. Ruzzenente A, Guglielmi A, Sandri M, Campagnaro T, Valdegamberi A, Conci S, Bagante F, Turcato G, D’Onofrio M, Iacono C. Surgical resection versus local ablation for HCC on cirrhosis: results from a propensity case-matched study. J Gastrointest Surg 2012;16:301-11; discussion 11.

26. Luo J, Peng ZW, Guo RP, Zhang YQ, Li JQ, Chen MS, Shi M. Hepatic resection versus transarterial lipiodol chemoembolization as the initial treatment for large, multiple, and resectable hepatocellular carcinomas: a prospective nonrandomized analysis. Radiology 2011;259:286-95.

27. Zhou L, Rui JA, Wang SB, Chen SG, Qu Q. Prognostic factors of solitary large hepatocellular carcinoma: the importance of differentiation grade. Eur J Surg Oncol 2011;37:521-5.

28. Chang WT, Kao WY, Chau GY, Su CW, Lei HJ, Wu JC, Hsia CY, Lui WY, King KL, Lee SD. Hepatic resection can provide long-term survival of patients with non-early-stage hepatocellular carcinoma: extending the indication for resection? Surgery 2012;152:809-20.

29. Galun DA, Bulajic P, Zuvela M, Basaric D, Ille T, Milicevic MN. Is there any benefit from expanding the criteria for the resection of hepatocellular carcinoma in cirrhotic liver? Experience from a developing country. World J Surg 2012;36:1657-65.

30. Huang JF, Wu SM, Wu TH, Lee CF, Wu TJ, Yu MC, Chan KM, Lee WC. Liver resection for complicated hepatocellular carcinoma: challenges but opportunity for long-term survivals. J Surg Oncol 2012;106:959-65.

31. Shrager B, Jibara GA, Tabrizian P, Schwartz ME, Labow DM, Hiotis S. Resection of large hepatocellular carcinoma $(>/=10 \mathrm{~cm})$ : a unique western perspective. J Surg Oncol 2013;107:111-7.

32. Allemann P, Demartines N, Bouzourene H, Tempia A, Halkic N. Long-term outcome after liver resection for hepatocellular carcinoma larger than $10 \mathrm{~cm}$. World J Surg 2013;37:452-8.

33. Ariizumi S, Kotera Y, Takahashi Y, Katagiri S, Yamamoto M. Impact of hepatectomy for huge solitary hepatocellular carcinoma. J Surg Oncol 2013;107:408-13.

34. Yin L, Li H, Li AJ, Lau WY, Pan ZY, Lai EC, Wu MC, Zhou WP. Partial hepatectomy vs. transcatheter arterial chemoembolization for resectable multiple hepatocellular carcinoma beyond Milan Criteria: a RCT. J Hepatol 2014;61:82-8.

35. Chan YC, Kabiling CS, Pillai VG, Aguilar G, Wang CC, Chen CL. Survival outcome between hepatic resection and transarterial embolization for hepatocellular carcinoma more than $10 \mathrm{~cm}$ : a propensity score model. World J Surg 2015;39:1510-8.

36. Chang YJ, Chung KP, Chang YJ, Chen LJ. Long-term survival of patients undergoing liver resection for very large hepatocellular carcinomas. Br J Surg 2016;103:1513-20.

37. Liu PH, Su CW, Hsu CY, Hsia CY, Lee YH, Huang YH, Lee RC, Lin HC, Huo TI. Solitary large hepatocellular carcinoma: staging and treatment strategy. PLoS One 2016;11:e0155588.

38. Zhao HC, Wu RL, Liu FB, Zhao YJ, Wang GB, Zhang ZG, Huang F, Xie K, Geng XP. A retrospective analysis of long term outcomes in patients undergoing hepatic resection for large ( $>5 \mathrm{~cm}$ ) hepatocellular carcinoma. HPB (Oxford) 2016;18:943-9.

39. Jin YJ, Lee JW. Therapeutic priorities for solitary large hepatocellular carcinoma in a hepatitis B virus endemic area; an analysis of a nationwide cancer registry database. J Surg Oncol 2017;115:407-16.

40. Kumada K, Ozawa K, Okamoto R, Takayasu T, Yamaguchi M, Yamamoto Y, Higashiyama H, Morikawa S, Sasaki H, Shimahara Y. Hepatic resection for advanced hepatocellular carcinoma with removal of portal vein tumor thrombi. Surgery 1990;108:821-7.

41. Llovet JM, Bru C, Bruix J. Prognosis of hepatocellular carcinoma: the BCLC staging classification. Semin Liver Dis 1999;19:329-38.

42. Ban D, Shimada K, Yamamoto Y, Nara S, Esaki M, Sakamoto Y, Kosuge T. Efficacy of a hepatectomy and a tumor thrombectomy for hepatocellular carcinoma with tumor thrombus extending to the main portal vein. $J$ Gastrointest Surg 2009;13:1921-8.

43. Peng ZW, Guo RP, Zhang YJ, Lin XJ, Chen MS, Lau WY. Hepatic resection versus transcatheter arterial chemoembolization for the treatment of hepatocellular carcinoma with portal vein tumor thrombus. Cancer 2012;118:4725-36.

44. Kojima H, Hatano E, Taura K, Seo S, Yasuchika K, Uemoto S. Hepatic resection for hepatocellular carcinoma with tumor thrombus in the major portal vein. Dig Surg 2015;32:413-20.

45. Kokudo T, Hasegawa K, Matsuyama Y, Takayama T, Izumi N, Kadoya M, Kudo M, Ku Y, Sakamoto M, Nakashima O, Kaneko S, Kokudo $\mathrm{N}$; Liver Cancer Study Group of Japan. Survival benefit of liver resection for hepatocellular carcinoma associated with portal vein invasion. J Hepatol 2016;65:938-43.

46. Roayaie S, Jibara G, Taouli B, Schwartz M. Resection of hepatocellular carcinoma with macroscopic vascular invasion. Ann Surg Oncol 2013;20:3754-60.

47. Lee JM, Jang BK, Lee YJ, Choi WY, Choi SM, Chung WJ, Hwang JS, Kang KJ, Kim YH, Chauhan AK, Park SY, Tak WY, Kweon YO, Kim BS, Lee CH. Survival outcomes of hepatic resection compared with transarterial chemoembolization or sorafenib for hepatocellular carcinoma with portal vein tumor thrombosis. Clin Mol Hepatol 2016;22:160-7.

48. Liu PH, Lee YH, Hsia CY, Hsu CY, Huang YH, Chiou YY, Lin HC, Huo TI. Surgical resection versus transarterial chemoembolization for hepatocellular carcinoma with portal vein tumor thrombosis: a propensity score analysis. Ann Surg Oncol 2014;21:1825-33.

49. Zheng N, Wei X, Zhang D, Chai W, Che M, Wang J, Du B. Hepatic resection or transarterial chemoembolization for hepatocellular carcinoma with portal vein tumor thrombus. Medicine (Baltimore) 2016;95:e3959.

50. Chen JS, Wang Q, Chen XL, Huang XH, Liang LJ, Lei J, Huang JQ, Li DM, Cheng ZX. Clinicopathologic characteristics and surgica outcomes of hepatocellular carcinoma with portal vein tumor thrombosis. $J$ Surg Res 2012;175:243-50.

51. Li N, Feng S, Xue J, Wei XB, Shi J, Guo WX, Lau WY, Wu MC, Cheng SQ, Meng Y. Hepatocellular carcinoma with main portal vein tumor thrombus: a comparative study comparing hepatectomy with or without neoadjuvant radiotherapy. HPB (Oxford) 2016;18:549-56.

52. Matono R, Yoshiya S, Motomura T, Toshima T, Kayashima H, Masuda T, Yoshizumi T, Taketomi A, Shirabe K, Maehara Y. Factors linked to longterm survival of patients with hepatocellular carcinoma accompanied by tumour thrombus in the major portal vein after surgical resection. HPB (Oxford) 2012;14:247-53. 
53. Shi J, Lai EC, Li N, Guo WX, Xue J, Lau WY, Wu MC, Cheng SQ. Surgical treatment of hepatocellular carcinoma with portal vein tumor thrombus. Ann Surg Oncol 2010;17:2073-80.

54. Tang QH, Li AJ, Yang GM, Lai EC, Zhou WP, Jiang ZH, Lau WY, Wu MC. Surgical resection versus conformal radiotherapy combined with TACE for resectable hepatocellular carcinoma with portal vein tumor thrombus: a comparative study. World J Surg 2013;37:1362-70.

55. Torzilli G, Belghiti J, Kokudo N, Takayama T, Capussotti L, Nuzzo G, Vauthey JN, Choti MA, De Santibanes E, Donadon M, Morenghi E, Makuuchi M. A snapshot of the effective indications and results of surgery for hepatocellular carcinoma in tertiary referral centers: is it adherent to the EASL/AASLD recommendations? An observational study of the HCC East-West study group. Ann Surg 2013;257:929-37.

56. Kudo M, Izumi N, Ichida T, Ku Y, Kokudo N, Sakamoto M, Takayama T, Nakashima O, Matsui O, Matsuyama Y. Report of the 19th follow-up survey of primary liver cancer in Japan. Hepatol Res 2016;46:372-90.

57. Chok KS, Cheung TT, Chan SC, Poon RT, Fan ST, Lo CM. Surgical outcomes in hepatocellular carcinoma patients with portal vein tumor thrombosis. World J Surg 2014;38:490-6.

58. Zhang YF, Le Y, Wei W, Zou RH, Wang JH, OuYang HY, Xiao CZ, Zhong XP, Shi M, Guo RP. Optimal surgical strategy for hepatocellular carcinoma with portal vein tumor thrombus: a propensity score analysis. Oncotarget 2016;7:38845-56.

59. Llovet JM, Schwartz M, Mazzaferro V. Resection and liver transplantation for hepatocellular carcinoma. Semin Liver Dis 2005;25:181-200.

60. Schwartz M, Roayaie S, Konstadoulakis M. Strategies for the management of hepatocellular carcinoma. Nat Clin Pract Oncol 2007;4:42432.

61. Matsui O, Kadoya M, Yoshikawa J, Gabata T, Arai K, Demachi H, Miyayama S, Takashima T, Unoura M, Kogayashi K. Small hepatocellular carcinoma: treatment with subsegmental transcatheter arterial embolization. Radiology 1993;188:79-83.

62. Groupe d'Etude et de Traitement du Carcinome Hépatocellulaire. A comparison of lipiodol chemoembolization and conservative treatment for unresectable hepatocellular carcinoma. N Engl J Med 1995;332:1256-61.

63. Raoul JL, Guyader D, Bretagne JF, Heautot JF, Duvauferrier R, Bourguet P, Bekhechi D, Deugnier YM, Gosselin M. Prospective randomized trial of chemoembolization versus intra-arterial injection of 131I-labeled-iodized oil in the treatment of hepatocellular carcinoma. Hepatology 1997;26:1156-61.

64. Bruix J, Llovet JM, Castells A, Montana X, Bru C, Ayuso MC, Vilana R, Rodes J. Transarterial embolization versus symptomatic treatment in patients with advanced hepatocellular carcinoma: results of a randomized, controlled trial in a single institution. Hepatology 1998;27:1578-83.

65. Pelletier G, Ducreux M, Gay F, Luboinski M, Hagege H, Dao T, Van Steenbergen W, Buffet C, Rougier P, Adler M, Pignon JP, Roche A. Treatment of unresectable hepatocellular carcinoma with lipiodol chemoembolization: a multicenter randomized trial. Groupe CHC. $J$ Hepatol 1998;29:129-34.

66. Llovet JM, Real MI, Montana X, Planas R, Coll S, Aponte J, Ayuso C, Sala M, Muchart J, Sola R, Rodes J, Bruix J; Barcelona Liver Cancer Group. Arterial embolisation or chemoembolisation versus symptomatic treatment in patients with unresectable hepatocellular carcinoma: a randomised controlled trial. Lancet 2002;359:1734-9.

67. Lo CM, Ngan H, Tso WK, Liu CL, Lam CM, Poon RT, Fan ST, Wong J. Randomized controlled trial of transarterial lipiodol chemoembolization for unresectable hepatocellular carcinoma. Hepatology 2002;35:1164-71.

68. Llovet JM, Bruix J. Systematic review of randomized trials for unresectable hepatocellular carcinoma: chemoembolization improves survival. Hepatology 2003;37:429-42.

69. Jianyong L, Lunan Y, Wentao W, Yong Z, Bo L, Tianfu W, Minqing X, Jiaying Y. Barcelona clinic liver cancer stage B hepatocellular carcinoma: transarterial chemoembolization or hepatic resection? Medicine (Baltimore) 2014;93:e180

70. Lee YB, Lee DH, Cho Y, Yu SJ, Lee JH, Yoon JH, Lee HS, Kim HC, Yi NJ, Lee KW, Suh KS, Chung JW, Kim YJ. Comparison of transarterial chemoembolization and hepatic resection for large solitary hepatocellular carcinoma: a propensity score analysis. $J$ Vasc Interv Radiol 2015;26:651-9.

71. Nouso K, Kariyama K, Nakamura S, Oonishi A, Wakuta A, Oyama A, Ako S, Dohi C, Wada N, Morimoto Y, Takeuchi Y, Kuwaki K, Onishi H, Ikeda F, Shiraha H, Takaki A, Okada H. Application of radiofrequency ablation for the treatment of intermediate-stage hepatocellular carcinoma. J Gastroenterol Hepatol 2017;32:695-700.

72. Xue T, Le F, Chen R, Xie X, Zhang L, Ge N, Chen Y, Wang Y, Zhang B, Ye S, Ren Z. Transarterial chemoembolization for huge hepatocellular carcinoma with diameter over ten centimeters: a large cohort study. Med Oncol 2015;32:64.

73. Leng JJ, Xu YZ, Dong JH. Efficacy of transarterial chemoembolization for hepatocellular carcinoma with portal vein thrombosis: a metaanalysis. ANZ J Surg 2016;86:816-20.

74. Ajit Y, Sudarsan H, Saumya G, Abhishek A, Navneet R, Piyush R, Anil A, Arun G. Transarterial chemoembolization in unresectable hepatocellular carcinoma with portal vein thrombosis: a perspective on survival. Oman Med J 2014;29:430-6.

75. Chern MC, Chuang VP, Liang CT, Lin ZH, Kuo TM. Transcatheter arterial chemoembolization for advanced hepatocellular carcinoma with portal vein invasion: safety, efficacy, and prognostic factors. $J$ Vasc Interv Radiol 2014;25:32-40.

76. Choi JW, Kim HC, Lee JH, Yu SJ, Kim YJ, Yoon JH, Jae HJ, Hur S, Lee M, Chung JW. Transarterial chemoembolization of hepatocellular carcinoma with segmental portal vein tumour thrombus. Eur Radiol 2017;27:1448-58

77. Gorodetski B, Chapiro J, Schernthaner R, Duran R, Lin M, Lee H, Lenis D, Stuart EA, Nonyane BA, Pekurovsky V, Tamrazi A, Gebauer B, Schlachter T, Pawlik TM, Geschwind JF. Advanced-stage hepatocellular carcinoma with portal vein thrombosis: conventional versus drugeluting beads transcatheter arterial chemoembolization. Eur Radiol 2017;27:526-35.

78. Niu ZJ, Ma YL, Kang P, Ou SQ, Meng ZB, Li ZK, Qi F, Zhao C. Transarterial chemoembolization compared with conservative treatment for advanced hepatocellular carcinoma with portal vein tumor thrombus: using a new classification. Med Oncol 2012;29:2992-7.

79. Lammer J, Malagari K, Vogl T, Pilleul F, Denys A, Watkinson A, Pitton M, Sergent G, Pfammatter T, Terraz S, Benhamou Y, Avajon Y, Gruenberger T, Pomoni M, Langenberger H, Schuchmann M, Dumortier J, Mueller C, Chevallier P, Lencioni R; PRECISION V Investigators. Prospective randomized study of doxorubicin-eluting-bead embolization in the treatment of hepatocellular carcinoma: results of the PRECISION V study. Cardiovasc Intervent Radiol 2010;33:41-52. 
80. Sacco R, Bargellini I, Bertini M, Bozzi E, Romano A, Petruzzi P, Tumino E, Ginanni B, Federici G, Cioni R, Metrangolo S, Bertoni M, Bresci G, Parisi G, Altomare E, Capria A, Bartolozzi C. Conventional versus doxorubicin-eluting bead transarterial chemoembolization for hepatocellular carcinoma. J Vasc Interv Radiol 2011;22:1545-52.

81. Recchia F, Passalacqua G, Filauri P, Doddi M, Boscarato P, Candeloro G, Necozione S, Desideri G, Rea S. Chemoembolization of unresectable hepatocellular carcinoma: Decreased toxicity with slow-release doxorubicineluting beads compared with lipiodol. Oncol Rep 2012;27:1377-83.

82. Gao YJ, He YJ, Yang ZL, Shao HY, Zuo Y, Bai Y, Chen H, Chen XC, Qin FX, Tan S, Wang J, Wang L, Zhang L. Increased integrity of circulating cell-free DNA in plasma of patients with acute leukemia. Clin Chem Lab Med 2010;48:1651-6.

83. Huang YJ, Hsu HC, Wang CY, Wang CJ, Chen HC, Huang EY, Fang FM, Lu SN. The treatment responses in cases of radiation therapy to portal vein thrombosis in advanced hepatocellular carcinoma. Int J Radiat Oncol Biol Phys 2009;73:1155-63.

84. Gao S, Yang Z, Zheng Z, Yao J, Deng M, Xie H, Zheng S, Zhou L. Doxorubicin-eluting bead versus conventional TACE for unresectable hepatocellular carcinoma: a meta-analysis. Hepatogastroenterology 2013;60:813-20.

85. Oliveri RS, Wetterslev J, Gluud C. Transarterial (chemo)embolisation for unresectable hepatocellular carcinoma. Cochrane Database Syst Rev 2011;(3):CD004787.

86. Hilgard P, Hamami M, Fouly AE, Scherag A, Muller S, Ertle J, Heusner T, Cicinnati VR, Paul A, Bockisch A, Gerken G, Antoch G. Radioembolization with yttrium-90 glass microspheres in hepatocellular carcinoma: European experience on safety and long-term survival. Hepatology 2010;52:1741-9.

87. Sangro B, Carpanese L, Cianni R, Golfieri R, Gasparini D, Ezziddin S, Paprottka PM, Fiore F, Van Buskirk M, Bilbao JI, Ettorre GM, Salvatori R, Giampalma E, Geatti O, Wilhelm K, Hoffmann RT, Izzo F, Inarrairaegui M, Maini CL, Urigo C, Cappelli A, Vit A, Ahmadzadehfar H, Jakobs TF, Lastoria S; European Network on Radioembolization with Yttrium-90 Resin Microspheres (ENRY). Survival after yttrium-90 resin microsphere radioembolization of hepatocellular carcinoma across Barcelona clinic liver cancer stages: a European evaluation. Hepatology 2011;54:868-78.

88. Salem R, Lewandowski RJ, Kulik L, Wang E, Riaz A, Ryu RK, Sato KT, Gupta R, Nikolaidis P, Miller FH, Yaghmai V, Ibrahim SM, Senthilnathan S, Baker T, Gates VL, Atassi B, Newman S, Memon K, Chen R, Vogelzang RL, Nemcek AA, Resnick SA, Chrisman HB, Carr J, Omary RA, Abecassis M, Benson AB 3rd, Mulcahy MF. Radioembolization results in longer time-to-progression and reduced toxicity compared with chemoembolization in patients with hepatocellular carcinoma. Gastroenterology 2011;140:497-507 e2.

89. Salem R, Lewandowski RJ, Mulcahy MF, Riaz A, Ryu RK, Ibrahim S, Atassi B, Baker T, Gates V, Miller FH, Sato KT, Wang E, Gupta R, Benson AB, Newman SB, Omary RA, Abecassis M, Kulik L. Radioembolization for hepatocellular carcinoma using Yttrium-90 microspheres: a comprehensive report of long-term outcomes. Gastroenterology 2010;138:52-64.

90. Carr BI, Kondragunta V, Buch SC, Branch RA. Therapeutic equivalence in survival for hepatic arterial chemoembolization and yttrium 90 microsphere treatments in unresectable hepatocellular carcinoma: a two-cohort study. Cancer 2010;116:1305-14.

91. Kim DY, Park BJ, Kim YH, Han KH, Cho SB, Cho KR, Uhm SH, Choe JG, Choi JY, Chun HJ, Lee HC, Gwon DI, Lee KH, Yoon JH, Chung JW, Kim CW, Heo J, Kim JK, Joo YE. Radioembolization with yttrium-90 resin microspheres in hepatocellular carcinoma: a multicenter prospective study. Am J Clin Oncol 2015;38:495-501.

92. Mazzaferro V, Sposito C, Bhoori S, Romito R, Chiesa C, Morosi C, Maccauro M, Marchiano A, Bongini M, Lanocita R, Civelli E, Bombardieri E, Camerini T, Spreafico C. Yttrium-90 radioembolization for intermediate-advanced hepatocellular carcinoma: a phase 2 study. Hepatology 2013;57:1826-37.

93. Moreno-Luna LE, Yang JD, Sanchez W, Paz-Fumagalli R, Harnois DM, Mettler TA, Gansen DN, de Groen PC, Lazaridis KN, Narayanan Menon KV, Larusso NF, Alberts SR, Gores GJ, Fleming CJ, Slettedahl SW, Harmsen WS, Therneau TM, Wiseman GA, Andrews JC, Roberts LR. Efficacy and safety of transarterial radioembolization versus chemoembolization in patients with hepatocellular carcinoma. Cardiovasc Intervent Radiol 2013;36:714-23.

94. El Fouly A, Ertle J, El Dorry A, Shaker MK, Dechene A, Abdella H, Mueller S, Barakat E, Lauenstein T, Bockisch A, Gerken G, Schlaak JF. In intermediate stage hepatocellular carcinoma: radioembolization with yttrium 90 or chemoembolization? Liver Int 2015;35:627-35.

95. Cappelli A, Pettinato C, Golfieri R. Transarterial radioembolization using yttrium-90 microspheres in the treatment of hepatocellular carcinoma: a review on clinical utility and developments. J Hepatocell Carcinoma 2014;1:163-82.

96. Sacco R, Conte C, Tumino E, Parisi G, Marceglia S, Metrangolo S, Eggenhoffner R, Bresci G, Cabibbo G, Giacomelli L. Transarterial radioembolization for hepatocellular carcinoma: a review. J Hepatocell Carcinoma 2016;3:25-9.

97. Russell AH, Clyde C, Wasserman TH, Turner SS, Rotman M. Accelerated hyperfractionated hepatic irradiation in the management of patients with liver metastases: results of the RTOG dose escalating protocol. Int J Radiat Oncol Biol Phys 1993;27:117-23.

98. Matsuo Y, Yoshida K, Nishimura H, Ejima Y, Miyawaki D, Uezono H, Ishihara T, Mayahara H, Fukumoto T, Ku Y, Yamaguchi M, Sugimoto K, Sasaki R. Efficacy of stereotactic body radiotherapy for hepatocellular carcinoma with portal vein tumor thrombosis/inferior vena cava tumor thrombosis: evaluation by comparison with conventional three-dimensional conformal radiotherapy. J Radiat Res 2016;57:512-23.

99. Bae SH, Kim MS, Cho CK, Kim KB, Lee DH, Han CJ, Park SC, Kim YH. Feasibility and efficacy of stereotactic ablative radiotherapy for Barcelona Clinic Liver Cancer-C stage hepatocellular carcinoma. J Korean Med Sci 2013;28:213-9.

100. Culleton S, Jiang H, Haddad CR, Kim J, Brierley J, Brade A, Ringash J, Dawson LA. Outcomes following definitive stereotactic body radiotherapy for patients with Child-Pugh B or C hepatocellular carcinoma. Radiother Oncol 2014;111:412-7.

101. Bujold A, Massey CA, Kim JJ, Brierley J, Cho C, Wong RK, Dinniwell RE, Kassam Z, Ringash J, Cummings B, Sykes J, Sherman M, Knox JJ, Dawson LA. Sequential phase I and II trials of stereotactic body radiotherapy for locally advanced hepatocellular carcinoma. $J$ Clin Oncol 2013;31:1631-9.

102. Lo CH, Yang JF, Liu MY, Jen YM, Lin CS, Chao HL, Huang WY. Survival and prognostic factors for patients with advanced hepatocellular carcinoma after stereotactic ablative radiotherapy. PLoS One 2017;12:e177793.

103. Toya R, Murakami R, Baba Y, Nishimura R, Morishita S, Ikeda O, Kawanaka K, Beppu T, Sugiyama S, Sakamoto T, Yamashita Y, Oya N. Conformal radiation therapy for portal vein tumor thrombosis of hepatocellular carcinoma. Radiother Oncol 2007;84:266-71. 
104. Oh D, Lim DH, Park HC, Paik SW, Koh KC, Lee JH, Choi MS, Yoo BC, Lim HK, Lee WJ, Rhim H, Shin SW, Park KB. Early threedimensional conformal radiotherapy for patients with unresectable hepatocellular carcinoma after incomplete transcatheter arterial chemoembolization: a prospective evaluation of efficacy and toxicity. Am J Clin Oncol 2010;33:370-5.

105. Cho JY, Paik YH, Park HC, Yu JI, Sohn W, Gwak GY, Choi MS, Lee JH, Koh KC, Paik SW, Yoo BC. The feasibility of combined transcatheter arterial chemoembolization and radiotherapy for advanced hepatocellular carcinoma. Liver Int 2014;34:795-801.

106. Leon SA, Shapiro B, Sklaroff DM, Yaros MJ. Free DNA in the serum of cancer patients and the effect of therapy. Cancer Res 1977;37:64650 .

107. Chan KC, Leung SF, Yeung SW, Chan AT, Lo YM. Persistent aberrations in circulating DNA integrity after radiotherapy are associated with poor prognosis in nasopharyngeal carcinoma patients. Clin Cancer Res 2008;14:4141-5.

108. Yoon SM, Lim YS, Won HJ, Kim JH, Kim KM, Lee HC, Chung YH, Lee YS, Lee SG, Park JH, Suh DJ. Radiotherapy plus transarterial chemoembolization for hepatocellular carcinoma invading the portal vein: long-term patient outcomes. Int J Radiat Oncol Biol Phys 2012;82:2004-11.

109. Okazaki E, Yamamoto A, Nishida N, Hamuro M, Ogino R, Hosono M, Shimatani Y, Tsutsumi S, Hamamoto S, Sohgawa E, Jogo A, Miki Y. Three-dimensional conformal radiotherapy for locally advanced hepatocellular carcinoma with portal vein tumour thrombosis: evaluating effectiveness of the model for end-stage liver disease (MELD) score compared with the Child-Pugh classification. Br J Radiol 2016;89:20150945.

110. Llovet JM, Ricci S, Mazzaferro V, Hilgard P, Gane E, Blanc JF, de Oliveira AC, Santoro A, Raoul JL, Forner A, Schwartz M, Porta C, Zeuzem S, Bolondi L, Greten TF, Galle PR, Seitz JF, Borbath I, Haussinger D, Giannaris T, Shan M, Moscovici M, Voliotis D, Bruix J; SHARP Investigators Study Group.. Sorafenib in advanced hepatocellular carcinoma. N Engl J Med 2008;359:378-90.

111. Cheng AL, Kang YK, Chen Z, Tsao CJ, Qin S, Kim JS, Luo R, Feng J, Ye S, Yang TS, Xu J, Sun Y, Liang H, Liu J, Wang J, Tak WY, Pan H, Burock K, Zou J, Voliotis D, Guan Z. Efficacy and safety of sorafenib in patients in the Asia-Pacific region with advanced hepatocellular carcinoma: a phase III randomised, double-blind, placebo-controlled trial. Lancet Oncol 2009;10:25-34.

112. Zhu AX, Rosmorduc O, Evans TR, Ross PJ, Santoro A, Carrilho FJ, Bruix J, Qin S, Thuluvath PJ, Llovet JM, Leberre MA, Jensen M, Meinhardt G, Kang YK. SEARCH: a phase III, randomized, double-blind, placebo-controlled trial of sorafenib plus erlotinib in patients with advanced hepatocellular carcinoma. J Clin Oncol 2015;33:559-66.

113. Cheng AL, Kang YK, Lin DY, Park JW, Kudo M, Qin S, Chung HC, Song X, Xu J, Poggi G, Omata M, Pitman Lowenthal S, Lanzalone S, Yang L, Lechuga MJ, Raymond E. Sunitinib versus sorafenib in advanced hepatocellular cancer: results of a randomized phase III trial. $J$ Clin Oncol 2013;31:4067-75.

114. Kudo M, Han G, Finn RS, Poon RT, Blanc JF, Yan L, Yang J, Lu L, Tak WY, Yu X, Lee JH, Lin SM, Wu C, Tanwandee T, Shao G, Walters IB, Dela Cruz C, Poulart V, Wang JH. Brivanib as adjuvant therapy to transarterial chemoembolization in patients with hepatocellular carcinoma: a randomized phase III trial. Hepatology 2014;60:1697-707.

115. Cainap C, Qin S, Huang WT, Chung IJ, Pan H, Cheng Y, Kudo M, Kang YK, Chen PJ, Toh HC, Gorbunova V, Eskens FA, Qian J, McKee MD, Ricker JL, Carlson DM, El-Nowiem S. Linifanib versus Sorafenib in patients with advanced hepatocellular carcinoma: results of a randomized phase III trial. J Clin Oncol 2015;33:172-9.

116. Cheng AL, Thongprasert S, Lim HY, Sukeepaisarnjaroen W, Yang TS, Wu CC, Chao Y, Chan SL, Kudo M, Ikeda M, Kang YK, Pan H, Numata K, Han G, Balsara B, Zhang Y, Rodriguez AM, Zhang Y, Wang Y, Poon RT. Randomized, open-label phase 2 study comparing frontline dovitinib versus sorafenib in patients with advanced hepatocellular carcinoma. Hepatology 2016;64:774-84.

117. Bruix J, Qin S, Merle P, Granito A, Huang YH, Bodoky G, Pracht M, Yokosuka O, Rosmorduc O, Breder V, Gerolami R, Masi G, Ross PJ, Song T, Bronowicki JP, Ollivier-Hourmand I, Kudo M, Cheng AL, Llovet JM, Finn RS, LeBerre MA, Baumhauer A, Meinhardt G, Han G; RESORCE Investigators. Regorafenib for patients with hepatocellular carcinoma who progressed on sorafenib treatment (RESORCE): a randomised, double-blind, placebo-controlled, phase 3 trial. Lancet 2017;389:56-66.

118. Kudo M. Immune checkpoint inhibition in hepatocellular carcinoma: basics and ongoing clinical trials. Oncology 2017;92 Suppl 1:50-62.

119. Whiteside TL, Demaria S, Rodriguez-Ruiz ME, Zarour HM, Melero I. Emerging opportunities and challenges in cancer immunotherapy. Clin Cancer Res 2016;22:1845-55.

120. Tomita Y, Fukasawa S, Shinohara N, Kitamura H, Oya M, Eto M, Tanabe K, Kimura G, Yonese J, Yao M, Motzer RJ, Uemura H, McHenry MB, Berghorn E, Ozono S. Nivolumab versus everolimus in advanced renal cell carcinoma: Japanese subgroup analysis from the CheckMate 025 study. Jpn J Clin Oncol 2017;47:639-46.

121. Weber JS, D’Angelo SP, Minor D, Hodi FS, Gutzmer R, Neyns B, Hoeller C, Khushalani NI, Miller WH, Jr., Lao CD, Linette GP, Thomas L, Lorigan P, Grossmann KF, Hassel JC, Maio M, Sznol M, Ascierto PA, Mohr P, Chmielowski B, Bryce A, Svane IM, Grob JJ, Krackhardt AM, Horak C, Lambert A, Yang AS, Larkin J. Nivolumab versus chemotherapy in patients with advanced melanoma who progressed after anti-CTLA-4 treatment (CheckMate 037): a randomised, controlled, open-label, phase 3 trial. Lancet Oncol 2015;16:375-84.

122. Sangro B, Gomez-Martin C, de la Mata M, Inarrairaegui M, Garralda E, Barrera P, Riezu-Boj JI, Larrea E, Alfaro C, Sarobe P, Lasarte JJ, Perez-Gracia JL, Melero I, Prieto J. A clinical trial of CTLA-4 blockade with tremelimumab in patients with hepatocellular carcinoma and chronic hepatitis C. J Hepatol 2013;59:81-8.

123. El-Khoueiry AB, Sangro B, Yau T, Crocenzi TS, Kudo M, Hsu C, Kim TY, Choo SP, Trojan J, Welling THR, Meyer T, Kang YK, Yeo W, Chopra A, Anderson J, Dela Cruz C, Lang L, Neely J, Tang H, Dastani HB, Melero I. Nivolumab in patients with advanced hepatocellular carcinoma (CheckMate 040): an open-label, non-comparative, phase 1/2 dose escalation and expansion trial. Lancet 2017;389:2492-502.

124. El-Serag HB. Epidemiology of viral hepatitis and hepatocellular carcinoma. Gastroenterology 2012;142:1264-73. e1.

125. Zhang YQ, Guo JS. Antiviral therapies for hepatitis B virus-related hepatocellular carcinoma. World J Gastroenterol 2015;21:3860-6.

126. Sparchez Z, Mocan T. Hepatocellular carcinoma occurrence and recurrence after antiviral treatment in HCV-related cirrhosis. Are outcomes different after direct antiviral agents? A review. J Gastrointestin Liver Dis 2017;26:403-10.

127. Yin J, Li N, Han Y, Xue J, Deng Y, Shi J, Guo W, Zhang H, Wang H, Cheng S, Cao G. Effect of antiviral treatment with nucleotide/ nucleoside analogs on postoperative prognosis of hepatitis B virus-related hepatocellular carcinoma: a two-stage longitudinal clinical study. 
J Clin Oncol 2013;31:3647-55.

128. Lao XM, Luo G, Ye LT, Luo C, Shi M, Wang D, Guo R, Chen M, Li S, Lin X, Yuan Y. Effects of antiviral therapy on hepatitis B virus reactivation and liver function after resection or chemoembolization for hepatocellular carcinoma. Liver Int 2013;33:595-604.

129. Kim JH, Park JW, Kim TH, Koh DW, Lee WJ, Kim CM. Hepatitis B virus reactivation after three-dimensional conformal radiotherapy in patients with hepatitis B virus-related hepatocellular carcinoma. Int J Radiat Oncol Biol Phys 2007;69:813-9.

130. Kubo S, Nishiguchi S, Hirohashi K, Tanaka H, Shuto T, Yamazaki O, Shiomi S, Tamori A, Oka H, Igawa S, Kuroki T, Kinoshita H. Effects of long-term postoperative interferon-alpha therapy on intrahepatic recurrence after resection of hepatitis $\mathrm{C}$ virus-related hepatocellular carcinoma. A randomized, controlled trial. Ann Intern Med 2001;134:963-7.

131. Mazzaferro V, Romito R, Schiavo M, Mariani L, Camerini T, Bhoori S, Capussotti L, Calise F, Pellicci R, Belli G, Tagger A, Colombo M, Bonino F, Majno P, Llovet JM; HCC Italian Task Force. Prevention of hepatocellular carcinoma recurrence with alpha-interferon after liver resection in HCV cirrhosis. Hepatology 2006;44:1543-54.

132. Conti F, Buonfiglioli F, Scuteri A, Crespi C, Bolondi L, Caraceni P, Foschi FG, Lenzi M, Mazzella G, Verucchi G, Andreone P, Brillanti S. Early occurrence and recurrence of hepatocellular carcinoma in HCV-related cirrhosis treated with direct-acting antivirals. J Hepatol 2016;65:727-33.

133. Reig M, Marino Z, Perello C, Inarrairaegui M, Ribeiro A, Lens S, Diaz A, Vilana R, Darnell A, Varela M, Sangro B, Calleja JL, Forns X, Bruix J. Unexpected high rate of early tumor recurrence in patients with HCV-related HCC undergoing interferon-free therapy. J Hepatol 2016;65:719-26.

134. Verslype C, Cohn AL, Kelley RK, Yang TS, Su WC, Ramies DA, Lee Y, Shen X, Cutsem EV. Activity of cabozantinib (XL184) in hepatocellular carcinoma: results from a phase II randomized discontinuation trial (RDT). J Clin Oncol 2012;30 Suppl 15:4007.

135. Kobayashi S, Ueshima K, Moriguchi M, Takayama T, Izumi N, Yoshiji H, Hino K, Oikawa T, Chiba T, Motomura K, Kato J, Yasuchika K, Ido A, Kinoshita J, Sato T, Ikeda M, Okusaka T, Kudo M, Tamura K, Furuse J. JET-HCC: a phase 3 randomized, double-blind, placebo-controlled study of tivantinib as a second-line therapy in patients with c-Met high hepatocellular carcinoma. Ann Oncol 2017;28:mdx369.003 